\title{
Large-scale solar district heating plants in Danish smart thermal grid: developments and recent trends
}

Article

Accepted Version

Creative Commons: Attribution-Noncommercial-No Derivative Works 4.0

Tian, Z., Zhang, S., Deng, J., Fan, J., Huang, J., Kong, W., Perers, B. and Furbo, S. (2019) Large-scale solar district heating plants in Danish smart thermal grid: developments and recent trends. Energy Conversion and Management, 189. pp. 67-80. ISSN 0196-8904 doi:

https://doi.org/10.1016/j.enconman.2019.03.071 Available at https://centaur.reading.ac.uk/83051/

It is advisable to refer to the publisher's version if you intend to cite from the work. See Guidance on citing.

To link to this article DOI: http://dx.doi.org/10.1016/j.enconman.2019.03.071

Publisher: Elsevier

All outputs in CentAUR are protected by Intellectual Property Rights law, including copyright law. Copyright and IPR is retained by the creators or other copyright holders. Terms and conditions for use of this material are defined in the End User Agreement. 


\section{CentAUR}

Central Archive at the University of Reading

Reading's research outputs online 


\title{
Large-scale solar district heating plants in Danish smart thermal grid: Developments and recent trends
}

\section{Zhiyong Tian ${ }^{1,4}$, Shicong Zhang ${ }^{2}$, Jie Deng ${ }^{3}$, Jianhua Fan ${ }^{4}$, Junpeng Huang ${ }^{4}$, Weiqiang Kong ${ }^{4}$, Bengt Perers ${ }^{4}$, Simon Furbo ${ }^{4}$}

\author{
1Department of Civil and Environmental Engineering, Norwegian University of Science and Technology, \\ Trondheim, Norway \\ 2 China Academy of Building Research, Beijing, 100013, China \\ 3 School of Construction Management and Engineering, University of Reading, Reading, United Kingdom \\ 4 Department of Civil Engineering, Technical University of Denmark, Brovej Building 118, Lyngby, 2800, \\ Denmark
}

\section{Abstracts}

Large solar collector fields are very popular in district heating system in Denmark, even though the solar radiation source is not favourable at high latitudes compared to many other regions. Business models for large solar heating plants in Denmark has attracted much attention worldwide. Denmark is not only the biggest country in both total installed capacities and numbers of large solar district heating plants, but also is the first and only country with commercial market-driven solar district heating plants. By the end of 2017, more than 1.3 million $\mathrm{m}^{2}$ solar district heating plants are in operation in Denmark. Furthermore, more than $70 \%$ of the large solar district heating plants worldwide are constructed in Denmark. Based on the case of Denmark, this study reviews the development of large solar district heating plants in Denmark since 2006. Success factors for Danish experiences was summarized and discussed. Novel design concepts of large solar district heating plants are also addressed to clarify the future development trend. Potential integration of large solar district heating plants with other renewable energy technologies are discussed. This paper can provide references to potential countries that want to exploit the market for solar district heating plants. Policymakers can evaluate the advantages and disadvantages of solar district heating systems in the national energy planning level based on the know-how and experiences from Denmark.

Keywords: Success factors; Large-scale solar district heating plants; Research \& Development; Denmark. 


\section{Introduction}

District energy systems are often more environmentally beneficial and financially reasonable when limited retrofit is required [1]. Currently, district heating networks are wellestablished in some countries and play an important role in district energy systems [2]. The building sector consumes $40 \%$ of total society energy consumption in European Union [3]. Space heating and domestic hot water has consumed more than $80 \%$ of energy consumption in the building sector [4]. 84\% of energy demand for space heating and domestic hot water are covered by fossil energy system, while only $16 \%$ comes from renewable energy [5]. Solar energy is widely used in electricity production, space heating and cooling, and domestic hot water system [6]. The advantages of solar systems are highlighted to reduce the management costs during mid-season periods and summer when an almost zero marginal cost thermal energy can displace the use of boilers [7]. Solar collector field should be integrated in the district energy systems based on the economic and energy optimizations [8]. The first largescale solar heating systems were introduced in Sweden in the late 70's [9]. Most of the early large solar seasonal storage heating plants are evaluated and reported in the IEA SHC Task 7"Central Solar Heating Plants With Seasonal Storage" for the period June 1979- June 1988 [10]. IEA SHC Task 45- "Large Scale Solar Heating and Cooling Systems" (Jan.2011Dec.2014) focused on cost effectiveness, high performance and reliability of large solar thermal systems [11]. IEA SHC Task 55 "Towards the Integration of Large SHC Systems into District Heating and Cooling (DHC) Network" (Sep.2016-Aug.2020) [12] also have been initiated to promote large-scale solar district heating around the world. Large solar district heating plants are installed in Europe rapidly during the last decades, particularly in Germany, Austria, and Denmark [13].

Perez-Mora et al. [14] presented four different types of solar district heating and cooling system in Europe. Germany put many efforts to develop 8 central solar heating plants with seasonal storage since 1995 [15]. Anders Tonhammar determined the technical, economic and environmental potential of a Solar District Heating facility, combined with a seasonal thermal storage, in the district heating network in Stockholm [16]. Reiter et al. [17] proposed a $500,000 \mathrm{~m}^{2}$ solar district heating plant for the whole city of Graz, Austria. Urbaneck et al. [18] found a solar fraction of about $10 \%$ can be reached easily from technical and economic points of view based on conventional district heating (DH) systems in east Germany. In addition, Bauer et al. [19] found that solar district heating systems together with seasonal storage with solar fraction above 50\% are technological and economic viability in a Germany project. It was also concluded that the great energy-saving and substitution potential of solar assisted district heating plants can be realized with a large scale if the cost of solar collector fields can be at a reasonable level [20]. Hassine et al. [21] recommended the extension of the solar collectors' area and the storage of solar heat to reach $100 \%$ solar fraction during the summer for an existing district heating network in Germany. Welsch et al. [22] suggested that medium deep borehole thermal energy storage systems in combination with a large solar thermal collector field and a small combined heat and power can be a cost-effective alternative to large CHPs for mitigating greenhouse gas emissions in district heating systems. 
Soloha et al. [23] discussed the possibilities and opportunities of implementing a large scale solar collector field accompanied by a seasonal water storage tank in a particular district heating facility in Latvia. It is concluded that solar district heating systems with seasonal storage tanks can be attractive in Latvia. Ciampi et al. [24] carried out thermo-economic sensitivity analysis by dynamic simulations of a small Italian solar district heating system with a seasonal borehole thermal energy storage. The results showed that primary energy consumption and carbon dioxide equivalent emission of the studied plant can be reduced by up to $6 \%$ and $4 \%$, respectively. Carotenuto et al. [25] did a dynamic simulation and energyeconomic analysis on novel solar-geothermal district heating, cooling and domestic hot water systems in the southern Italy. Felipe Andreu et al. [26] did an estimation of the solar heat cost for central solar heating plant with pit thermal seasonal storage based on the condition of Velika Gorica. It was highlighted that solar district heating system with underground thermal energy storage, supported by biomass energy, is an interesting technology for implementation in the Mediterranean's low-to-medium population density areas [27]. Similar findings were shown for Mediterranean climate regions that in the reference [28]. Mateo de Guadalfajara et al. [29] evaluated the potential of central solar heating plants with seasonal storage in Spain. Winterscheid et al. [30] showed that the integration of solar heat into existing district heating systems brings benefits of $\mathrm{CO}_{2}$ emission reduction and operation flexibility to district heating systems where heat is supplied mainly by fossil combined heat and power plants. Hirvonen et al. [31] investigated the potential of solar district heating systems in Finland. Optimal design and comparison of a centralized and semi-decentralized community size solar district heating system was carried out[32]. They found that solar district heating community can work at high latitude Nordic countries, like Finland [33]. Rämä et al. [34] also found that centralised solar heating systems within the lower range of reported investment costs represented a viable business case for renewable energy integration based on a case study of a local district heating system in Finland. Tulus et al. [35] presented the economic and environmental potential for solar assisted central heating plants in the EU residential sector. Nicolás Pardo García et al. [36] found that the use of Photovoltaic thermal hybrid solar collectors in combination with district heating for a Central European multi-family house provides important benefits in terms of sustainability, energy security, carbon abatement and costs. Salehi et al. [37] dicussed the feasibility of solar-assisted absorption heat pumps for space heating with exergoeconomics compared to gas boilers and solar heating systems for the town of Sarein in Iran. Bouhal et al. [38] did parametric study the thermal performance of a combined solar airconditioning, space heating and domestic hot water system and found it feasible with subsidies of $20 \%$ of initial investment cost from the government in Morocco. Pakere et al. [39] analyzed optimal integration of photovoltaic thermal hybrid (PVT) technology in district heating systems by covering industrial power consumption and heat demand of buildings in the Northern European climate. Jouhara et al. [40] also concluded that hybrid flat heat pipe solar PV/T roof collectors have potential contribution to district heating applications. Xu et al. [41] assessed the performance of a district heating systems with $1002 \mathrm{~m}^{2}$ solar collector field, industry excess heat, and large underground seasonal thermal energy storage in China. 
There are two very successful stories on large solar district heating systems. First one is the Drake Landing solar heating community in Canada [42]. More than 90\% solar fraction (space heating demand) has been achieved in Drake Landing solar heating community in the past five years [43]. This plant has been in reliable operation with no unscheduled interruptions in heating delivery operations. Reed et al.[44] investigated the potential of solar district heating plants in USA based on the Drake Landing solar heating community. The results showed that it was an attractive investment for solar district heating with underground thermal energy storage when compared with natural gas-based systems for the provision of residential space heating in North America. Renaldi et al. [45] also did techno-economic analysis of a solar district heating system with seasonal thermal storage in the UK based on the Drake Landing solar heating community. It is found that the systems is feasible in the UK. Flynn et al. [46] analysed the influence of location and design on the performance of a solar district heating system equipped with borehole seasonal storage using the Drake Landing solar heating community model. Model predictive control was carried out by Jose Quintana et al. [47] for Drake Landing solar heating community in order to reduce energy consumption of backup fossil systems. Similar research on Drake Landing solar heating community also can be found in the reference [48]. However, because solar heat in Canada cannot compete with natural gas boilers, there are not any other new large solar district heating systems which have been built in Canada after the Drake Landing solar heating community.

The other story is Danish solar district heating plants [49]. Denmark aims to get rid of fossil energy by 2050. A broad majority in the Danish Parliament entered an agreement in March 2012 on the 2020 climate strategy and a long-term target to reach 100\% renewable energy in the energy system by 2050. On contrary to the situation in Canada, solar district heating plants can compete with the heat price of natural gas boilers, since Danish government has energy tax on natural gas. Solar district heating plants are completely commercial solutions in Danish district energy systems. The cost-effectiveness of solar heating systems have to be investigated carefully during the plan and design phase. Arabkoohsar et al. [50] designed a bifunctional solar assisted absorption chiller district heating and cooling networks for Aarhus University Hospital. It was found that the proposed systems is very economical with short payback period. Bava et al. did a detailed analysis on a $3257 \mathrm{~m}^{2}$ solar heating plant in Denmark [51].

More than $64 \%$ heat demand of households are supplied by the district heating networks in Denmark. The Danish district heating system is expected to play a significant role in the following goals: (1) In 2020, wind turbines shall cover 50\% of the domestic electricity supply; (2) In 2035, all the electricity and heat supply shall come from renewable energy. On June 29 of 2018, the Danish government signed a new energy agreement with the support of all the sitting parties in the Danish parliament. The agreement reaffirms and strengthens Denmark's climate and energy goals leading up to 2030. The energy agreement contains a wide range of ambitious green initiatives and easing of electricity taxes, which will help Danish consumers to replace fossil energy with green electricity. Similarly, companies and consumers will receive cheaper heating through a modernisation of the heating sector. A modernisation of the 
heating sector, where both the district heating sector and the consumers have a free choice to decide future investments, resulting in cheap heating for both companies and consumers [52]. Figure 1 shows the future scenarios of district heating networks in Denmark. It can be seen clearly that the solar energy has more and more share in the near future.

More than 1.3 million square meter solar district heating plants have been installed in Denmark by the end of 2017. Furthermore, there are more than 100 large solar district heating plants installed in Denmark. Demark is the leading country in both solar district heating capacity and numbers of solar district heating plants around the world, see in Figure 2.

Large solar district heating plants have been installed fast in Denmark in the last decade. As shown in Figure 2, Denmark is far ahead of other countries in both installed numbers and capacities of large solar district heating systems. Figure 3 shows the development of large solar district heating plants from 2006. By the comparison of the scenarios in 2008 and 2016 in Figure 4, the market of solar district heating systems has the market blowout in the last decade around the whole Denmark. Denmark is not only the global-leader in the large-scale solar district heating plants, but also the only country with a mature and commercial market
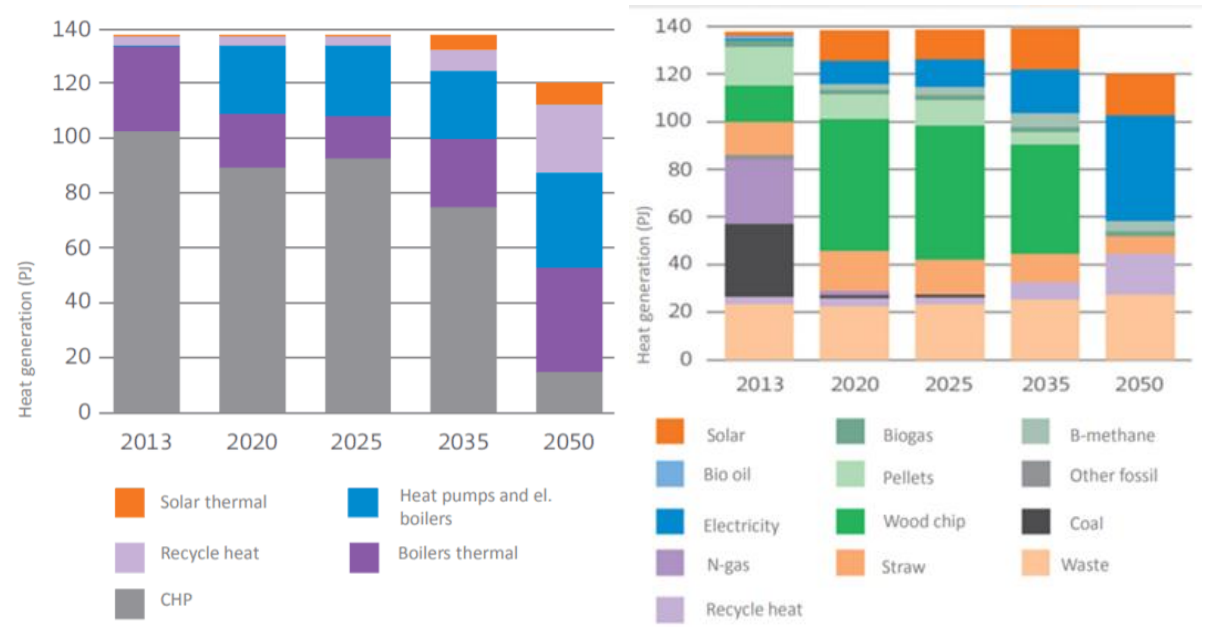

Figure 1 District heating scenarios in Denmark(Left:type of generation, Right: original source) [54]. 


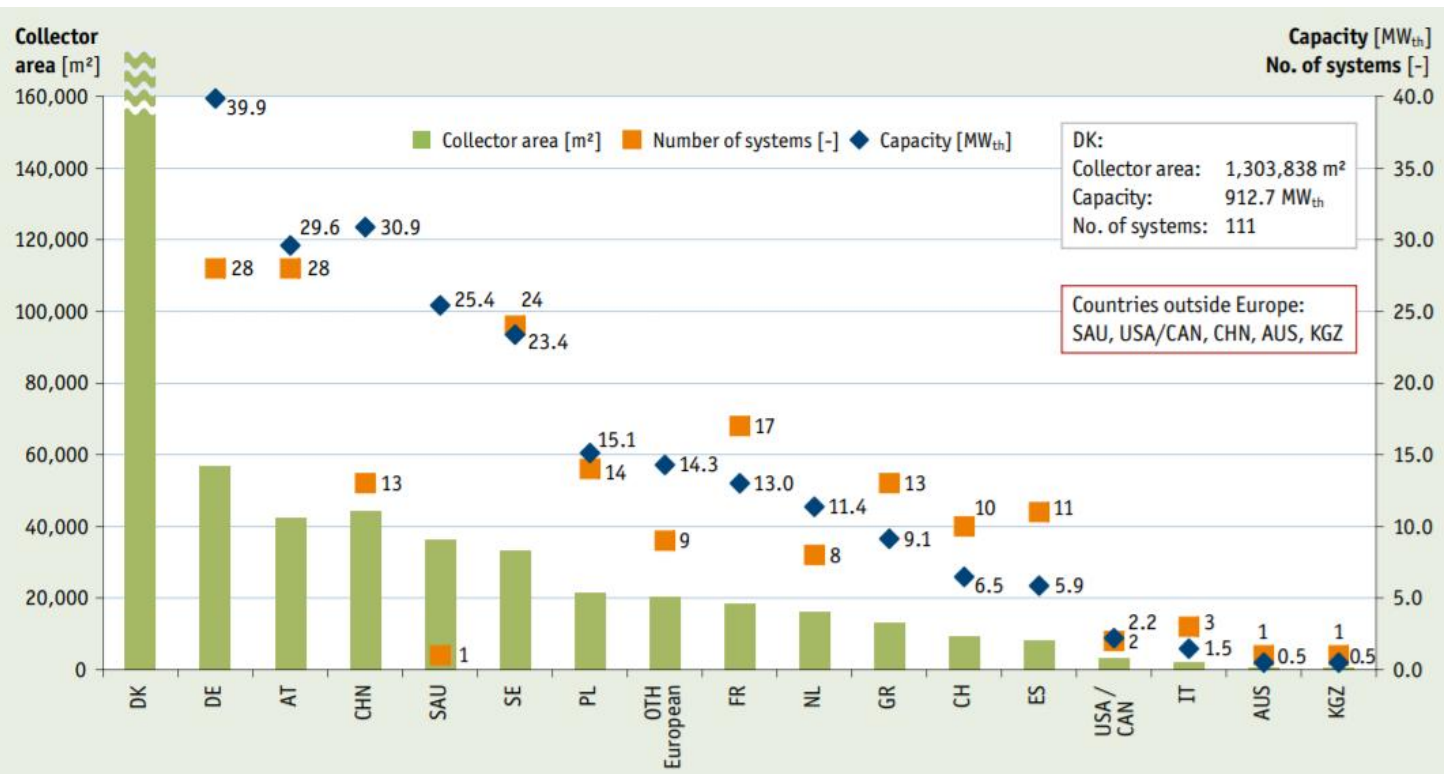

Figure 2 Large-scale systems for solar district heating and residential buildings - capacities and collector area installed and number of systems in 2017 [13].

\section{Solar District Heating in Denmark}

\section{Sum of collector area and the number of operating and upcoming plants}

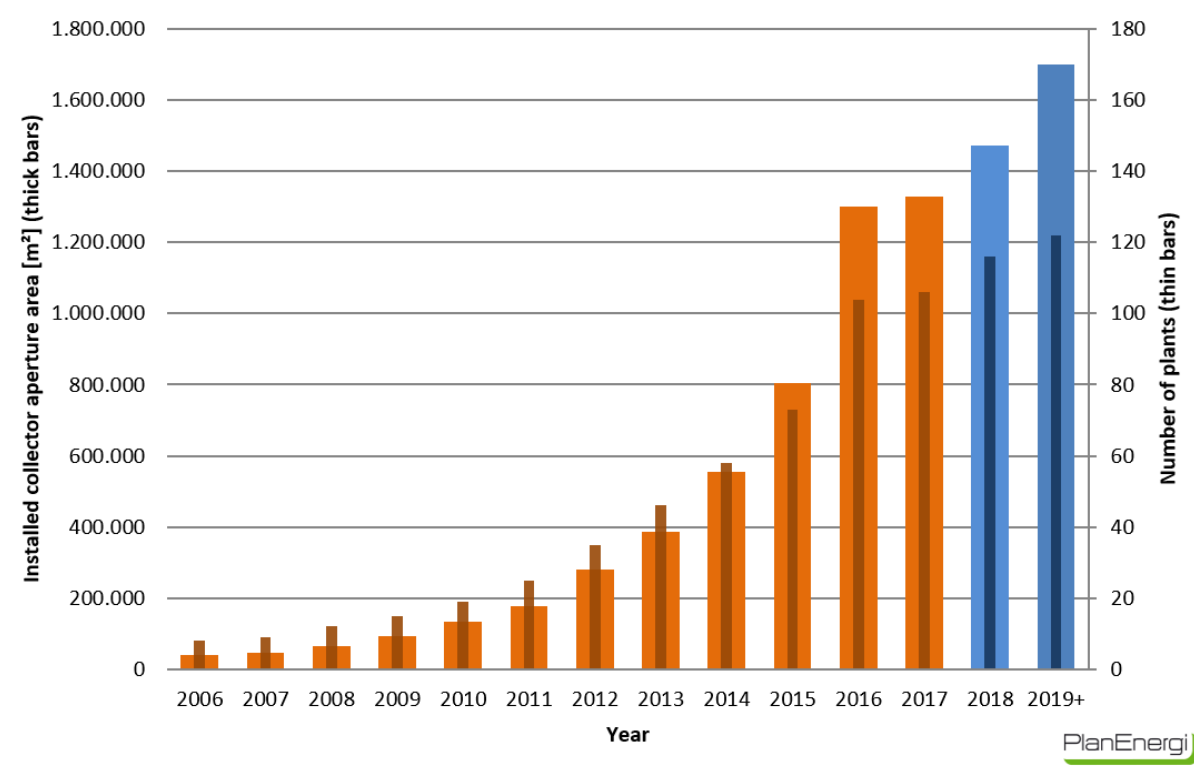

Figure 3 Development of solar district heating plants in Denmark since 2006 (Source: PlanEnergi)[55]. 

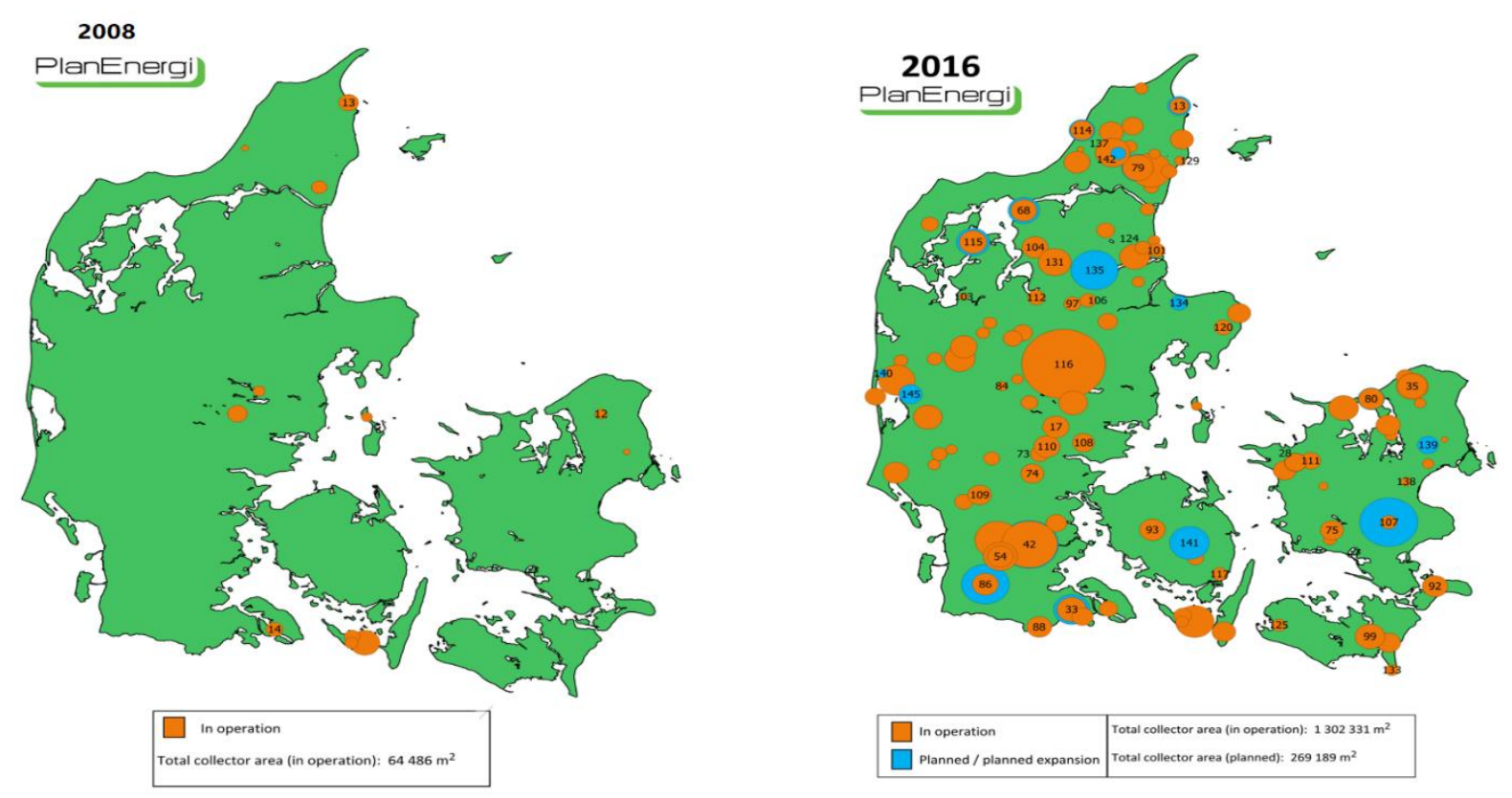

Figure 4 Distribution of solar distritc heating plants in Denmark [56].

Figure 5 shows examples of the large solar heating plants in Denmark. The first successful solar district heating plant was the Marstal solar heating plant, which was co-funded by the Danish Energy Agency in the Sunstore projects since 2003. The area of the solar collector field in Mastal is $33300 \mathrm{~m}^{2}$. Vojens plant with $70000 \mathrm{~m}^{2}$ solar collector was the largest solar district heating plant in the world in 2015 . Silkeborg plant with $0.16 \mathrm{~km}^{2}$ solar collector came to the first place in 2016, see in Figure 5. Water pit seasonal heat storages are used in solar heating plants to significantly increase solar fraction of the plant. The first water pit heat storage of $10000 \mathrm{~m}^{3}$ was demonstrated in Marstal in 2004. Then water pit storages with improved designs were constructed in Marstal $\left(75000 \mathrm{~m}^{3}, 2012\right)$, Dronninglund $\left(62000 \mathrm{~m}^{3}, 2014\right)$ and Vojens $(200000$ $\left.\mathrm{m}^{3}, 2015\right)$. To sum up, large solar district heating plants with tens of thousands square meter solar collector have developed very fast in the last decade in Denmark.

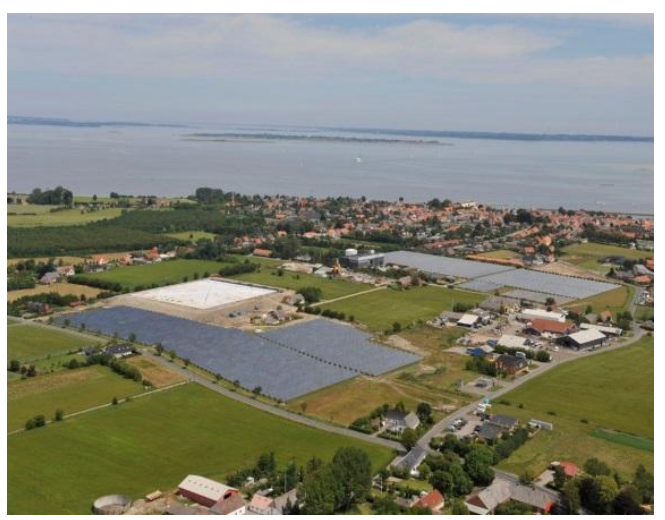

5a. Marstal plant $\left(33300 \mathrm{~m}^{2}\right)$

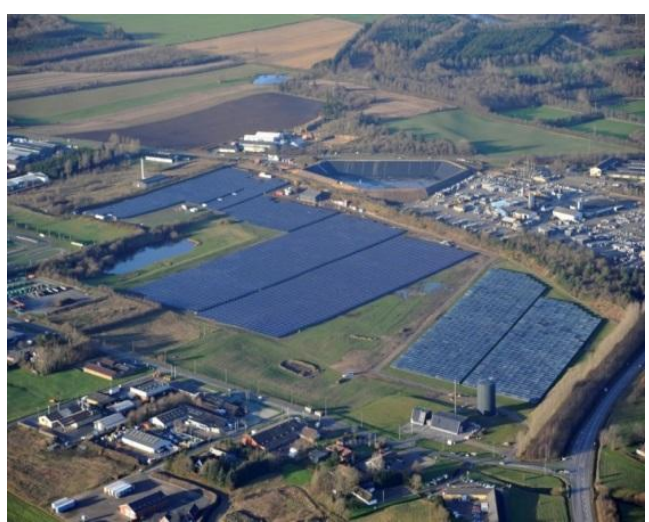

5b. Vojens plant $\left(70000 \mathrm{~m}^{2}\right)$ 


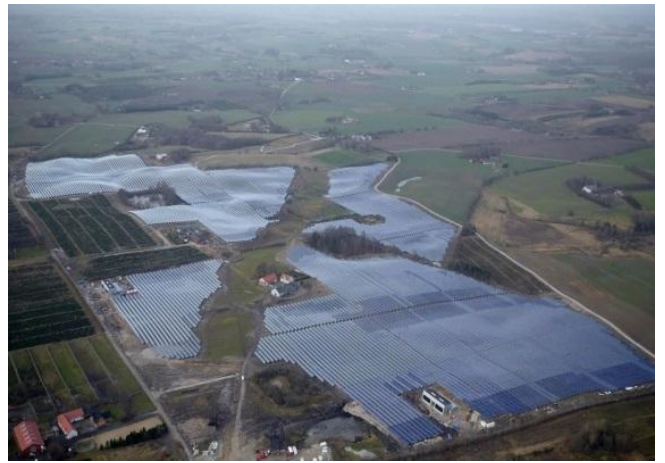

5c. Silkeborg plant $\left(156694 \mathrm{~m}^{2}\right)$

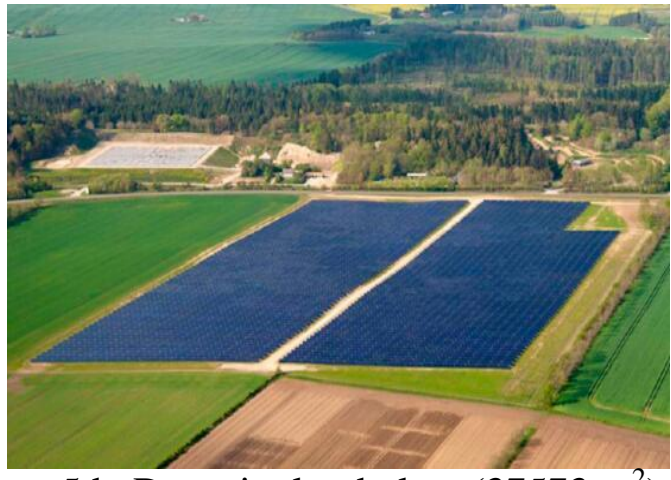

5d. Dronninglund plant $\left(37573 \mathrm{~m}^{2}\right)$

Figure 5 a-d Typical large solar heating plants in Denmark (source: Arcon-Sunmark A/S).

Trier et al. [57] reported the characters of Danish solar district heating plants in IEA SHC Task 52. It was found that the large-scale solar district heating plants may be feasible in most European countries. Denmark usually is famous for wind power in renewable energy sector. M.N Fisch et al. [58] gave an overview of large-scale solar district heating systems in Europe in 1998. Only Alfred Heller reported 15 Years of R\&D in central solar heating in Denmark in 2000 before the take-off of these systems [59]. Limited other scientific publications on comprehensive analysis on the great successful story of Danish solar district heating plants are found, as far as we know. It could be possible to have a similar development of large solar district heating in other countries [57]. Large solar district heating plants in Denmark are taken as example in this paper. This study summaries the development of large solar district heating plants in Denmark. The results not only can provide some reference design basis for large solar district heating plants for other countries, but also present the business models for other countries, where solar district heating can be included in the energy systems.

The paper is organized as follows: the $1^{\text {st }}$ section is the introduction; the $2^{\text {nd }}$ section is solar radiation analysis; the $3^{\text {rd }}$ section introduces the typical solar district heating plants in Denmark; the $4^{\text {th }}$ section summaries the research and development of solar district heating plants; the $5^{\text {th }}$ section and $6^{\text {th }}$ section are discussions and conclusions \& policy implications, respectively.

\section{Solar radiation analysis}

The yearly global radiation in Denmark is around $1000-1150 \mathrm{kWh} / \mathrm{m}^{2}$, as is shown in Figure 6. Solar radiation conditions in Denmark is not so favorable compared to many other regions worldwide [60], as shown in Figure 7. Solar collectors in Denmark are placed with an angle of approximately 30-40 degrees to get the maximum solar radiation, while also taking into consideration the cast of shadows. The total radiation on the tilted collector surfaces will be $1100-1200 \mathrm{kWh} / \mathrm{m}^{2}$ [60]. Yearly Direct Normal Irradiance (DNI) in Denmark is around $1000 \mathrm{kWh} / \mathrm{m}^{2}$. 


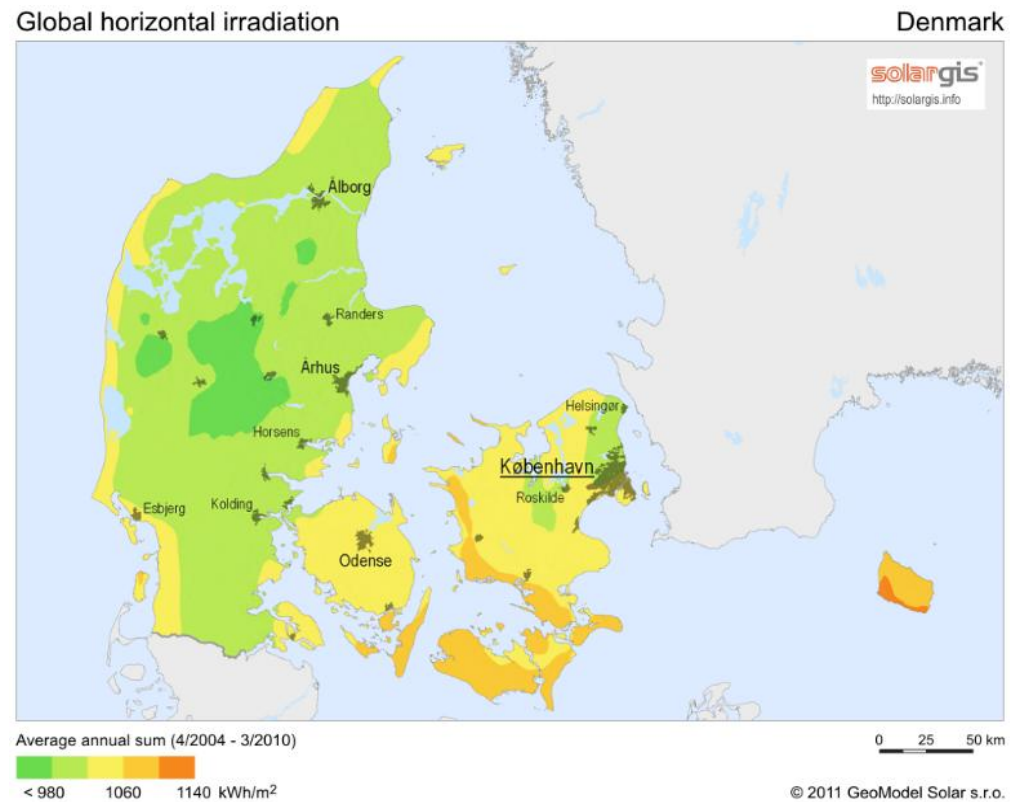

Figure 6 Global horizontal irradiation in Denmark (Source: Solargis) [61].

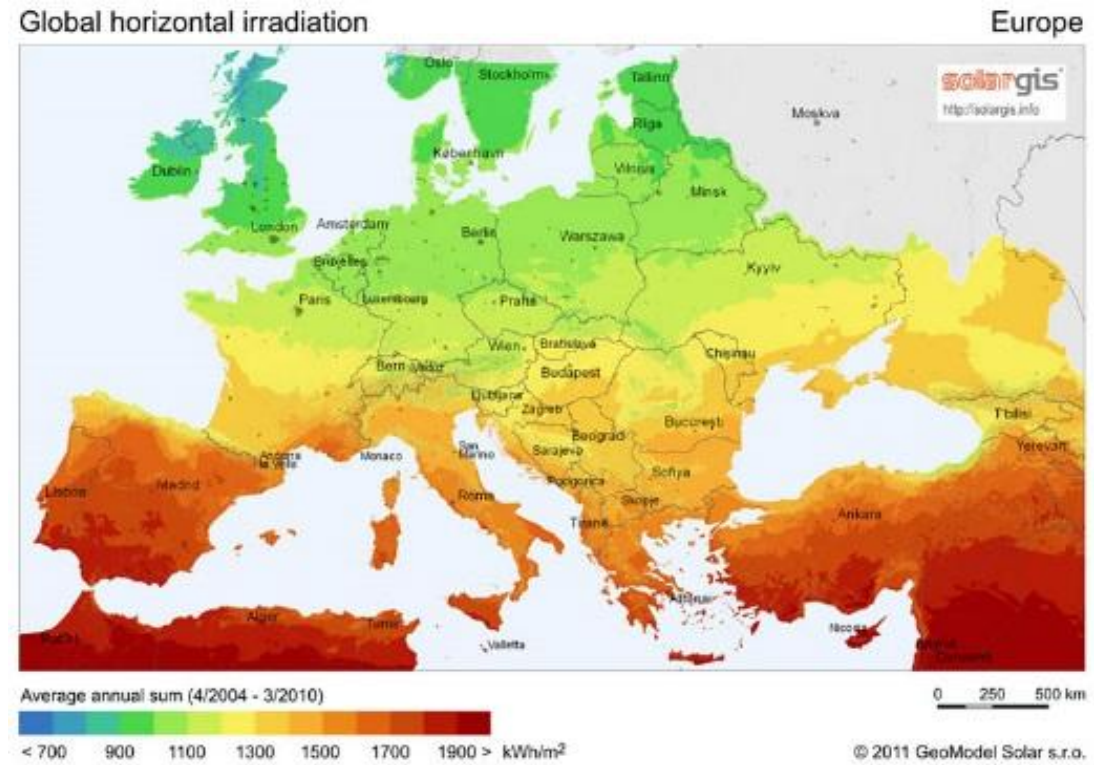

Figure 7 Global horizontal irradiation in Europe (source: Solargis) [61]. 


\section{Smart Danish solar district heating systems}

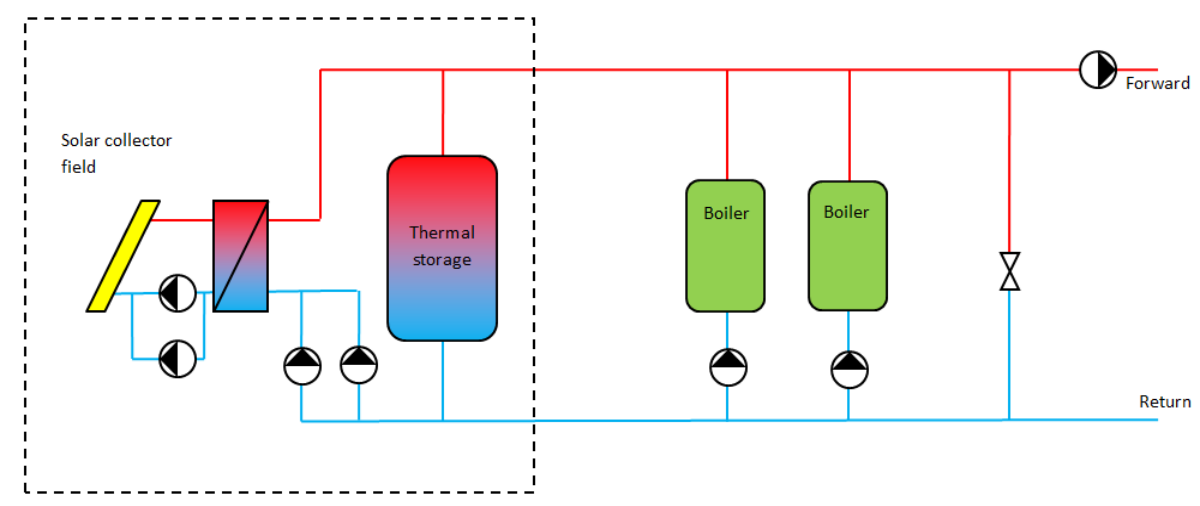

Figure 8 Schematic drawing of a typical system integration of solar district heating in Denmark (Source: PlanEnergi).

Figure 8 shows the typical system integration of solar district heating systems in Denmark. In most cases, the large solar collector field is just directly connected to the existing district heating networks by a flat plate heat exchanger. This principle is similar to the prospects in the reference [15] that solar renovation of existing district heating systems will become increasingly important as a way of reducing fossil energy demand and $\mathrm{CO}_{2}$-emissions in existing urban areas. Existing heat storages in district heating networks are used as diurnal storage component. The solar collector fields are located at the countryside, where the land is very cheap. Most district heating companies are non-profit, even owned by the communities. The main investment in solar heating plants are mainly solar collectors. If there are no complete district heating systems, the investment of the whole systems will be high, which is not a problem in Denmark. District heating is very popular in Denmark. More than 64\% of Danish household are connected to district heating networks. So there are very profound district heating networks in Denmark. Figure 9 and Figure 10 show the principle of Gram solar heating plants and Brædstrup solar heating plants, respectively. Solar heating plants in Gram combined water pit heat storage and heat pump to provide heat for district heating networks. The solar heating plant in Brædstrup is integrated with borehole heat storage to provide heat to district heating networks. Water pit storage and borehole storage are two common seasonal storage technologies in Denmark.

Furbo et al. [62] have summed up the thermal performance of solar district heating plants in Denmark. The average yearly solar heat of the plants is in the range of 400-460 $\mathrm{kWh} / \mathrm{m}^{2}$.The efficiency of the whole solar heating plants is around $40 \%$. The energy output of the solar district heating plants depends on the operation temperature of the district heating networks, storage capacity and so on. A 40-50\% efficiency of Danish solar district heating plants was also found by Noussan et al [63]. The good efficiency shows that the large-scale solar collector components used in district heating plants are very reliable products after many (up to 30) years' operation. 


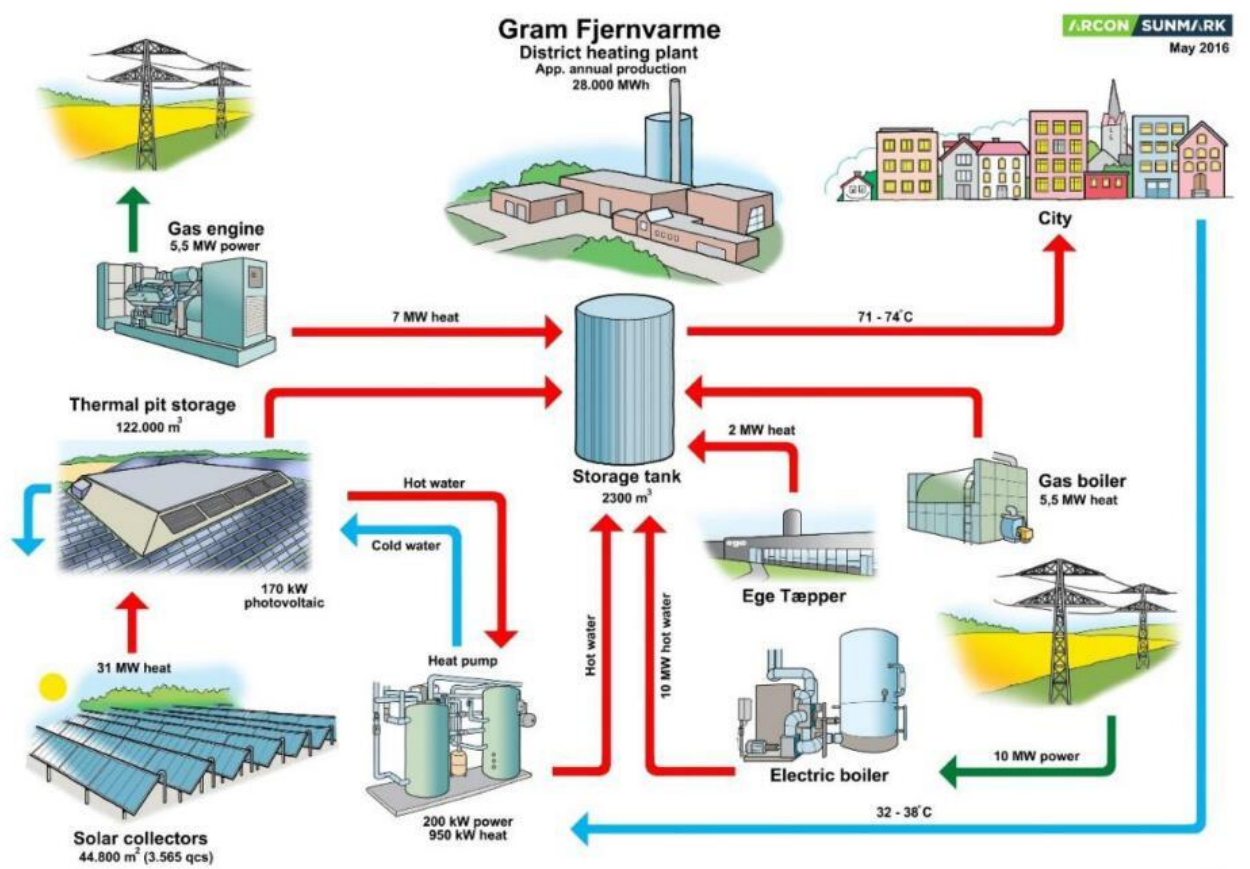

Figure 9 Gram solar heating plants in Denmark [64].

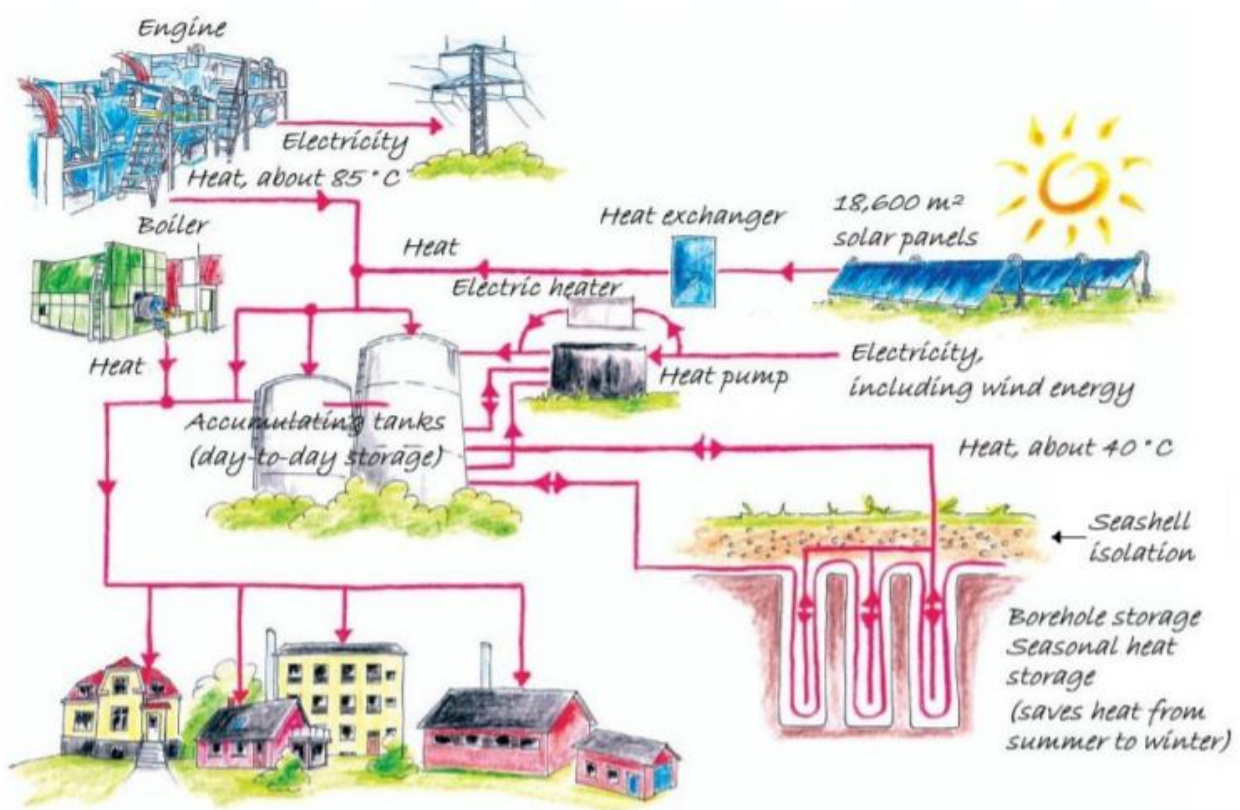

Figure 10 Bradstrup solar district heating plant in Denmark [65]. 


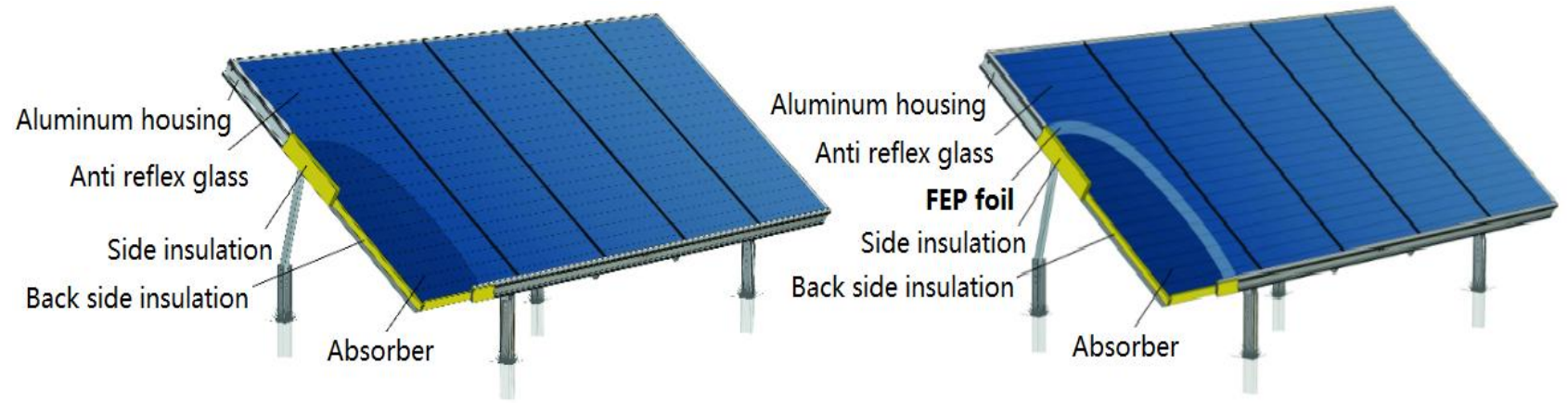

Figure 11 Typical large area solar collector without/with FEP foils (Source: Arcon-Sunmark A/S) [66].

Flat plate collector and evacuated tube collector are the common solar collectors in lowtemperature solar thermal systems below 100 degrees Celsius [67]. Solar collectors used in Denmark mainly are flat plate collectors, not widely used evacuated tube collector in Asia [68]. Flat plate collectors used in Danish large solar district heating plants have larger size than the normal ones in the market. The aperture area can be in the range between12.6-14.5 $\mathrm{m}^{2}$. The typical solar collectors used in Danish solar district heating plants can be found in Figure 11. The solar collectors with fluorinated ethylene propylene (FEP) foils have a bit lower optical efficiency and heat loss coefficient than the solar collectors without FEP foils. In order to gain higher solar heat production, the solar collectors without FEP foils in the front and that with FEP foils in the back are usually connected in series. The optical efficiency of both collectors are around 0.77-0.8. The parameters are available in the Solarkeymark [69]. The main manufacture of large flat plate collector delivered to solar heating plants in Denmark is Arcon-Sunmark A/S. GREENoneTEC also cooperates with Aalborg CSP A/S to expand its market. Savosolar ApS has delivered large flat plate collectors to a few plants in Denmark as well. All manufacturers have different design details, to improve the cost goal to get low costs and low pipe losses and good flow distribution. This is vital for good cost/performance ratio for a collector field and part of the success story.

\subsection{With/without seasonal heat storage}

Seasonal heat storage technology found its place favourably in solar energy system due to the seasonal mismatch between solar resources and heat demand [70]. Thermal storage will be more and more important for future energy system with high penetration of fluctuating renewable energy [71]. The typical heat storage solution for solar district heating plants is a cylindrical steel tank placed on the ground, used as diurnal storage. Typically, a steel tank is already installed at the existing district heating plants, when solar district heating systems are considered. This is because most plants interested in a solar heating system (as mentioned) are natural gas fired combined heat and power (CHP) plants, which normally use an accumulation tank to even out the demand fluctuations and to produce electricity and heat when the fluctuating electricity price is high, even if there is no or low demand for heat.

Typical solar fractions of solar heating plants are around 20\% in Denmark, if there is no seasonal heat storage [72]. The share of solar heating in a district heating system without heat 
storage is relatively low (5-8 \% of yearly heat demand). Hence, the most common application is the combination of a solar thermal system with a diurnal heat storage, which will enable approximately 20-25\% share of solar district heating in a district heating system. A typical Danish system with a short-term heat storage of $0.1-0.3 \mathrm{~m}^{3}$ per $\mathrm{m}^{2}$ solar collector covers correspondingly $10-25 \%$ of the annual heat demand. The ratio of storage volume/collector area as a function of solar fraction in Denmark can found in Figure 12. A cooling system to cope with surplus heat may be economically feasible and can help to reach a higher solar fraction without the installation of seasonal storage.

Moreover, the combination with a seasonal heat storage can increase the share of solar heating to 30-50 \% economically, and theoretically up to $100 \%$ with enough large solar collector fields. Hence, there is an important synergy with seasonal storage technologies. Towards solar district heating with more than $70 \%$ solar fraction has been found possible to achieve at reasonable costs compared to natural gas based CHP plant heat prices in Denmark [73].

Seasonal heat storage units normally have 4 types of designs: tank storage, water pit

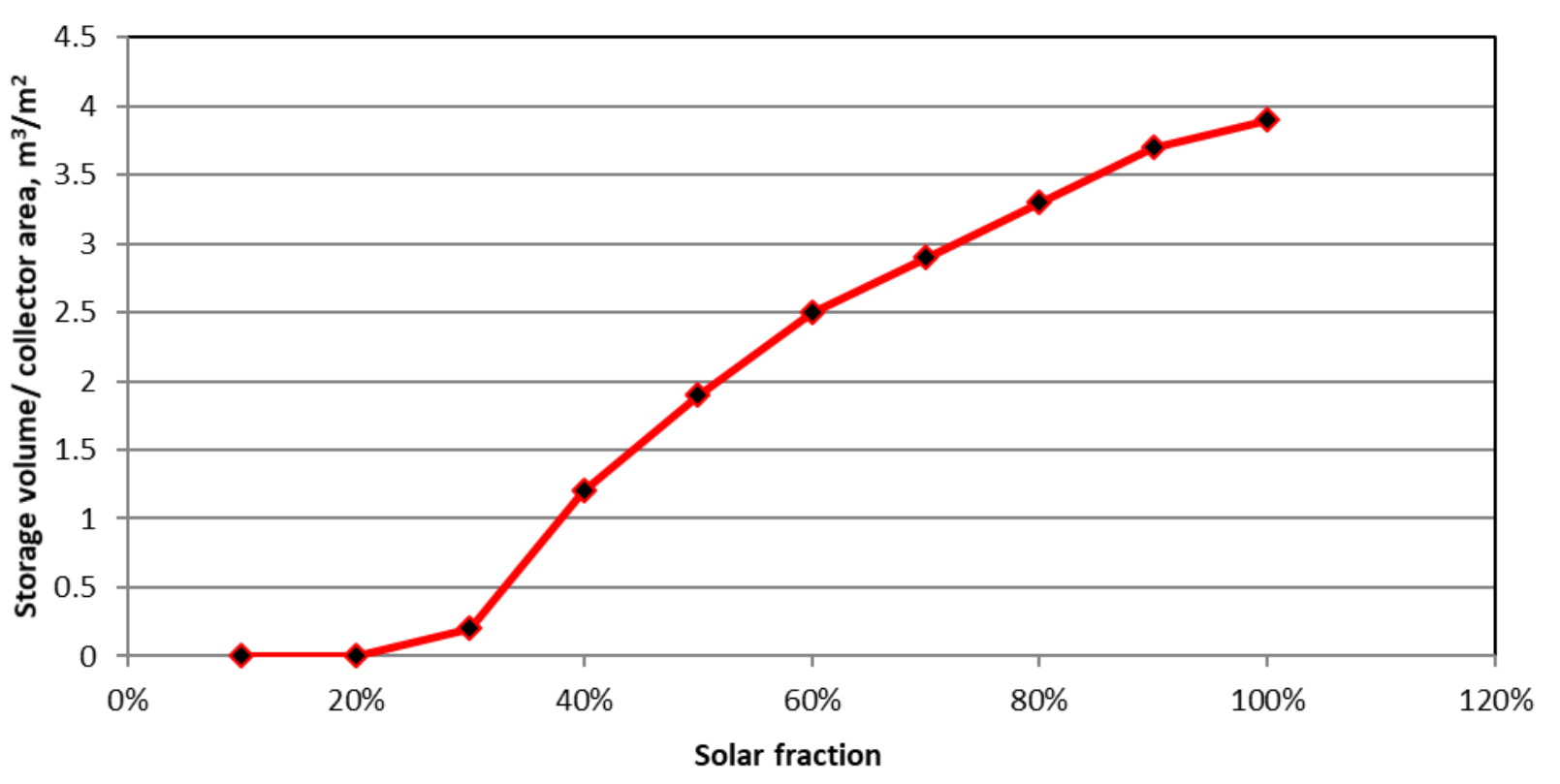



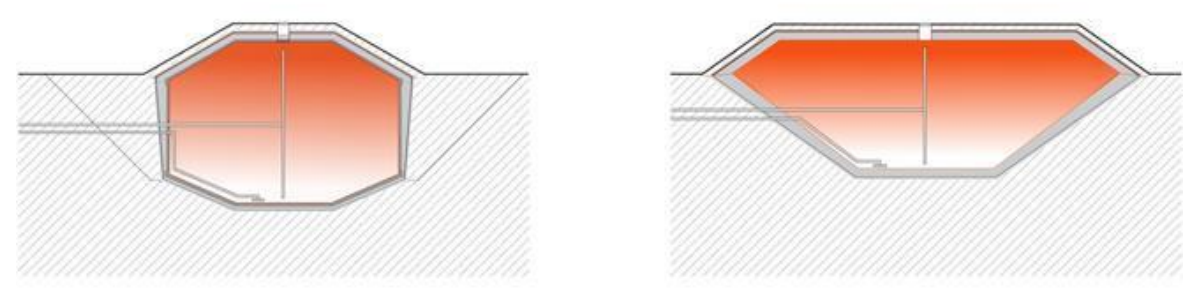

Borehole thermal energy storage (BTES)

(15 to $30 \mathrm{kWh} / \mathrm{m}^{3}$ )

Figure 13 Typical seasonal storage components (Source: Solites).

Table 1 Summary of seasonal heat storage in Denmark
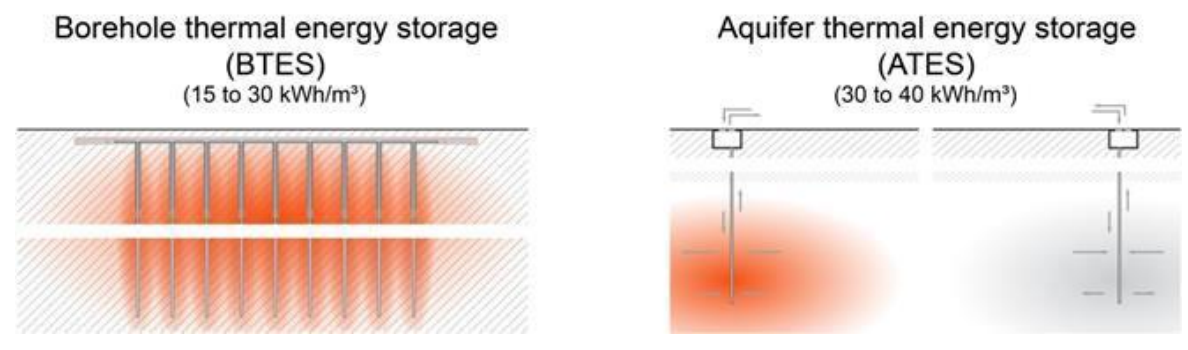

\begin{tabular}{cccc}
\hline Plant & Size, $\mathrm{m}^{3}$ & Type & Year \\
\hline Ottrup-gård & 1500 & Water pit & $1993-1995$ \\
Marstal & 10000 & Water pit & 2003 \\
Marstal & 75000 & Water pit & $2011 / 2012$ \\
Brædstrup & $19000($ soil $)$ & Borehole & $2011 / 2012$ \\
Dronninglund & 60000 & Water pit & 2013 \\
Vojens & 200000 & Water pit & $2014 / 2015$ \\
Gram & 122000 & Water pit & $2014 / 2015$ \\
Toftlund & 70000 & Water pit & $2016 / 2017$ \\
Høje Taastrup & $70000($ Planned $)$ & Water pit & 2019 (Planned) \\
\hline
\end{tabular}

3.3 Economic analysis

Olsthoorn et al. [76] summarized various variables of district heating systems can be optimized, including improvement of energy and exergy efficiency, life cycle analysis of costs, optimization of cost versus efficiency and reduction of greenhouse gases and pollutants. Levelized Cost of Heat ( $\mathrm{LCOH}$ ) has been proposed as the consistent evaluation criterion for solar thermal systems [77]. Normally the solar district heating plants are owned by the local communities. So it is interesting to compare the $\mathrm{LCOH}$ and heat production cost of other energy systems. Figure 14 shows the typical fuel fee and tax of typical energy systems in Denmark. 


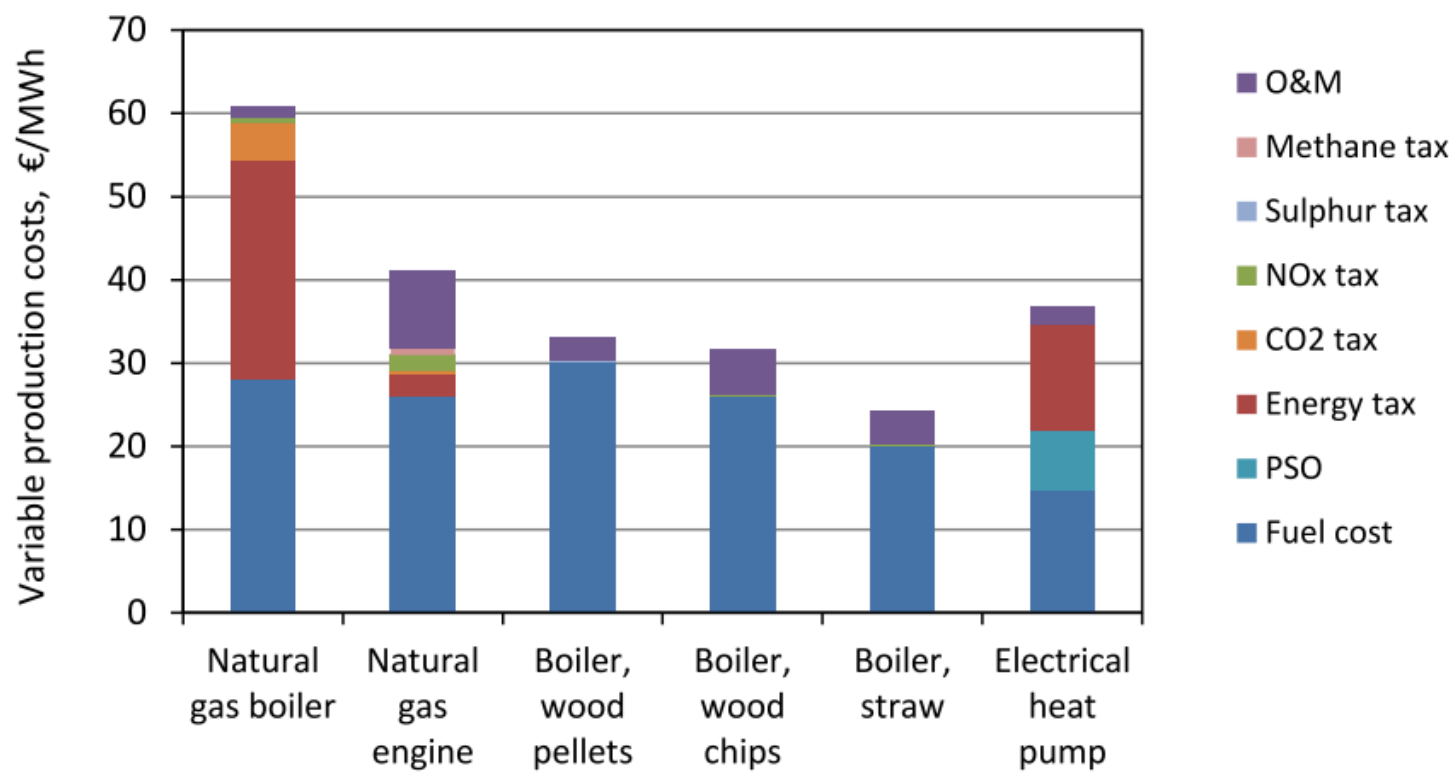

Figure 14 Fuel costs for heating production including taxes and VAT in Denmark [53].

The heat production cost of boiler wood pellets, wood chips and straw are lower than 35 EU/MWh. The heat production cost of electrical heat pump is around 37 EU/MWh. The heat price of the boiler straw is the lowest one, below $25 \mathrm{EU} / \mathrm{MWh}$. The heat price of natural gas boilers in Denmark can be the highest one, higher than $60 \mathrm{EU} / \mathrm{MWh}$. The heat price of solar heat can be in the range of 20-40 EU/MWh. The lowest heat price of solar district heating plants is only one third of that of natural gas boilers. Solar district heating plants are one kind of totally cost-effective heat sources for district heating networks in Denmark.

\section{New trends}

Even though Denmark has already been the dominated country in solar district heating plants, there are many research and developments to make Denmark as a frontrunner in solar district heating plants. Parabolic trough collectors and compound parabolic trough collectors are been testing in the pilot projects. $4^{\text {th }}$ generation district heating systems with low temperature and smart integration with other energy technologies also provide many potential for solar district heating plants [78]. New trends on solar district heating plants are introduced in this section.

\subsection{Parabolic trough collector}

Most collectors in existing solar district heating plants are large area flat plate collectors. Since 2013, Aalborg CSP A/S and Technical University of Denmark have started to investigate the potential of parabolic trough collectors in solar district heating plants in Denmark [79].

Parabolic trough collectors have not been regarded as a suitable technology for high latitude areas like in Denmark for a long time, even though a preliminary study in 2000 showed that parabolic trough collector can work under Danish climate conditions [80]. The 
efficiency of flat plate collectors decreases sharply with the increase of the operation temperature. Parabolic trough collectors have a constant and high efficiency regardless of operation temperature. There are three demonstration parabolic trough collector plants in Denmark.

In 2011, Aalborg CSP A/S was engaged in cooperation with the visionary Thisted Varmeforsyning in the establishment of a pilot project using concentrated solar power for district heating [81]. The plant is the first one in the world to use the CSP technology for district heating purposes. A prototype CSP plant in Thisted built by Aalborg CSP A/S has been monitored and evaluated during the spring and summer 2013. The performance of the Thisted was investigated by Technical University of Denmark (DTU). The results show that the parabolic trough collector can work under Danish conditions.

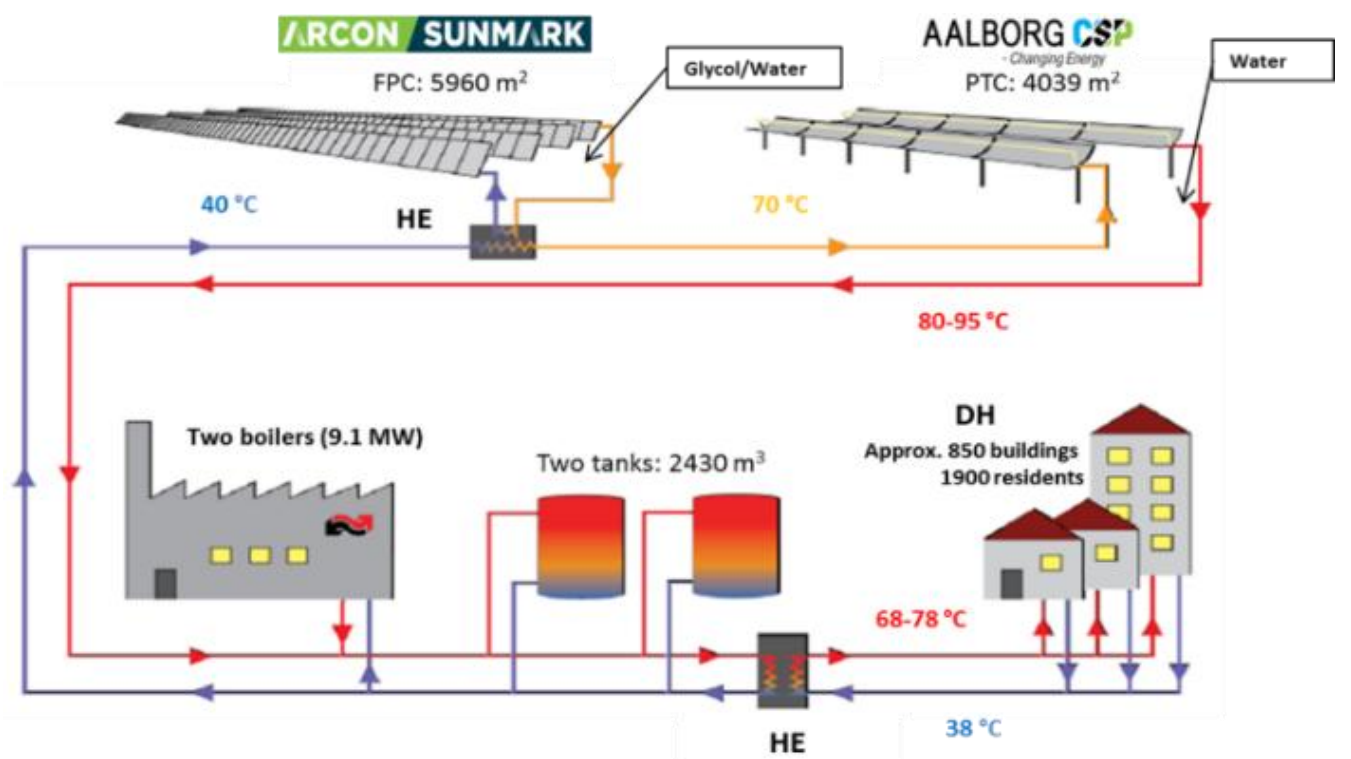

Figure 15 Taars plant: a combined solar district heating plant with flat plate collectors and parabolic trough collectors in series (Source: Aalborg CSP A/S) [81].

Detailed thermal performances are also presented to demonstrate the feasibility of parabolic trough collectors at high latitudes with low annual solar radiation resources [82].The combination of flat plate collectors and the parabolic trough collector technology in series is a perfect match as both systems deliver exactly what they do best: flat collectors have a higher performance at lower temperatures and produce more heat around midday, whereas parabolic trough collector is most efficient at high temperatures and provides a more balanced heat production throughout the day. The solar heating system for Taars Varmeværk applies flat collectors to preheat the water which is thereafter boosted by the parabolic trough collector technology to achieve the required supply temperature of the district heating network [83]. The mix of the two technologies allows better daily energy distribution [84]. A hybrid solar district heating plant with $5960 \mathrm{~m}^{2}$ flat plate collector field and $4039 \mathrm{~m}^{2}$ parabolic trough collector field in series was put into operation in August of 2015. The district heating network 
supplies heat to 2000 habitants/ 840 buildings. Detailed info about the yearly thermal performance can be found in the reference [85].

As suggested, the configuration with an organic Rankine cycle with solar thermal collectors and a biomass boiler is particularly attractive for large capacity plants [86]. Aalborg CSP A/S in close collaboration with the Danish district heating plant (Brønderslev Forsyning) carried out a comprehensive feasibility study on the potential to use concentrated solar power as an add-on to a biomass-ORC plant. Based on the positive findings, Aalborg CSP A/S was awarded the contract to develop and supply the 16.6 $\mathrm{MW}_{\text {th }}$ CSP plant enabling production of heat and electricity within one carbon-free system [87].

The CSP plant consists of 40 rows of $125 \mathrm{~m}$ long parabolic trough loops with an aperture area of 26,929 $\mathrm{m}^{2}$ [87]. The parabolic troughs (U-shaped mirrors) collect the suns' rays and reflect them onto a vacuum receiver pipe wherein a fluid is heated up to $330^{\circ} \mathrm{C}$. This high temperature is able to drive an electric turbine to produce electricity, but the flexibility of the system also allows production of lower temperatures for district heating purposes. To maximize the yield of energy, waste heat from organic Rankine cycle, is utilized and sent to the district heating circuit whereas electrical power is generated at peak price periods. Small scale parabolic trough collectors are also promoted for solar district heating systems by Absolicon Solar Collector AB, a Swedish company [88]. Performance of this small scale parabolic trough collector can be found in the reference [89]

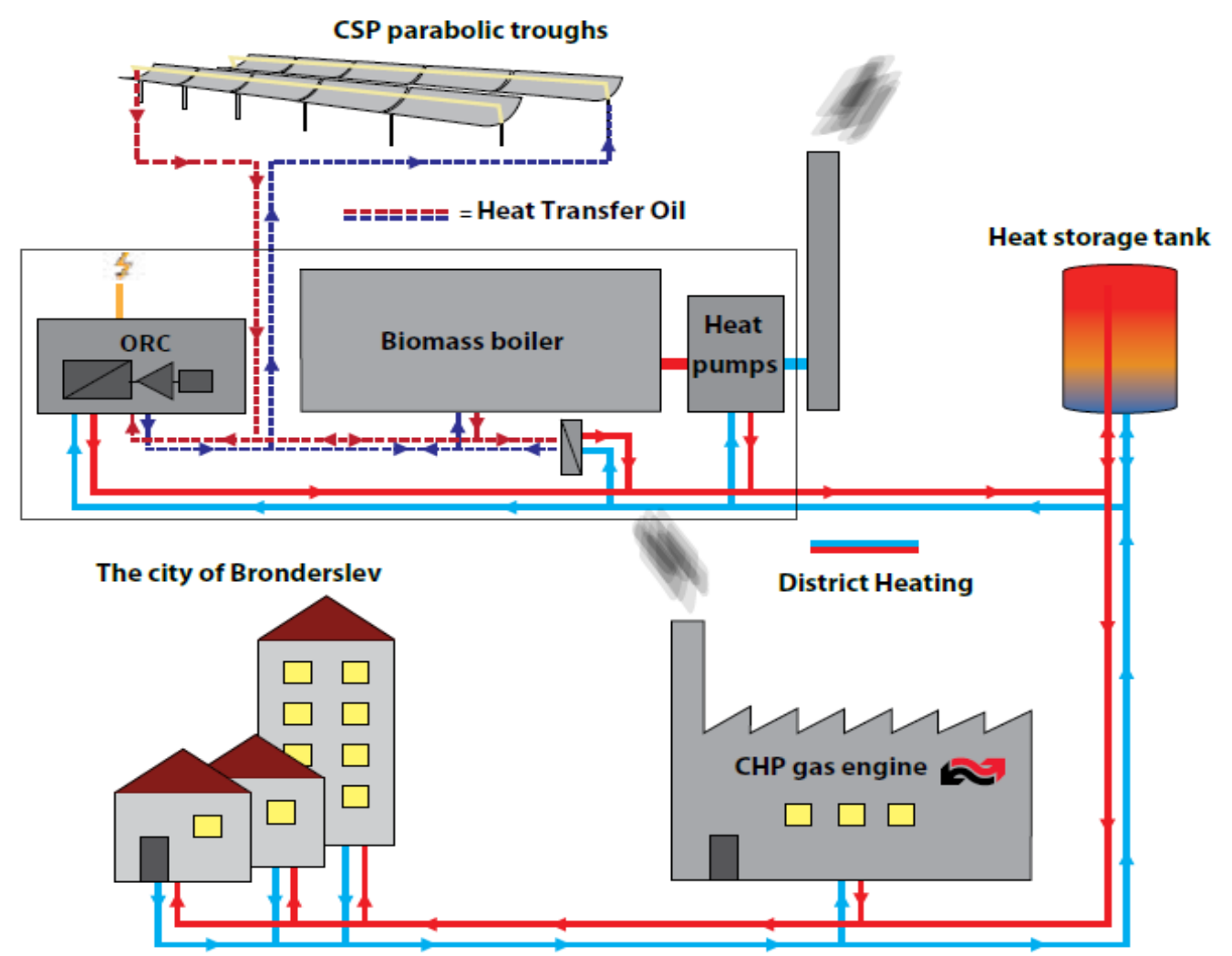


402

403

404

405

406

407

408

409

410

411

412

413

414

415

416

417

418

419

420

421

422

423

424

425

426

427

428

429

430

431

432

433

434
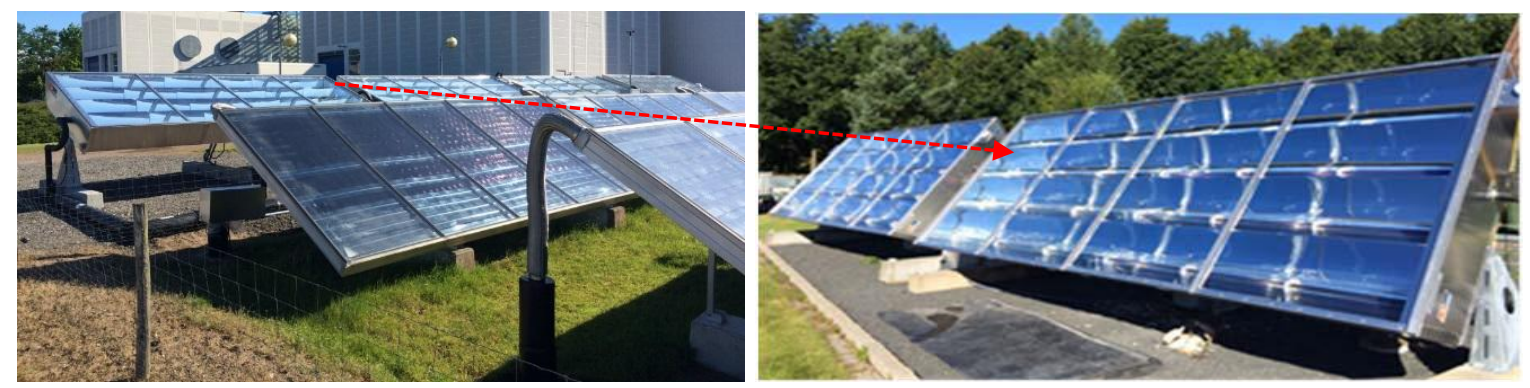

Figure 17 Compound parabolic trough collectors (Source: PolyCSP Aps/DTU)

A new concept of large compound parabolic collector (CPC) has been developed by the Danish company PolyCSP ApS for hybrid solar thermal heating plants. The design is especially optimized for the temperature range of $60{ }^{\circ} \mathrm{C}-120{ }^{\circ} \mathrm{C}$ for district heating application. Four CPC solar collectors were installed in series as the last array connected to the solar collector field in Sæby solar heating plant (http://www.saebyvarmevaerk.dk/), see Figure 17. The principle is similar to the Taars hybrid solar heating plant. The preheated water from flat plate collectors is further heated by the compound parabolic trough collectors to the required supply temperature of the district heating network.

\subsection{Low-temperature district heating systems}

In many Danish district heating networks, the flow temperature is around $80{ }^{\circ} \mathrm{C}$ or higher, and the return temperature around $40-45^{\circ} \mathrm{C}$. Many district heating companies have focused on reducing the temperatures in their networks, in some cases as low as $50 / 25{ }^{\circ} \mathrm{C}$ forward/return. In the future, even lower temperatures may be possible [90]. Lower temperature will results in several advantages: (1) Low temperature DH will reduce the heat loss of the pipe grid; (2) The flexibility of DH networks: the lower the required supply temperature is, the better the efficiency of heat pump and solar heating plants is.

\subsection{Integration with other energy technologies}

Integration of smart grids, energy storage and increased share of renewable energy is more and more interesting for district heating systems [91]. Previous studies also indicate that the introduction of heat pumps in Denmark will have a positive impact on the total costs for energy supply in the transition towards $100 \%$ renewable energy. In 2030, heat pumps are expected to cover around $15 \%$ of the net space heating demand of households. It has been revealed that solar district heating systems with seasonal thermal energy storage integrating heat pump are more energetically efficient than that without heat pump [92]. One study showed that the technical and private economic aspects of integrating a large capacity of electric driven heat pumps in the Greater Copenhagen district heating system, which is an example of a state-of-the-art large district heating system with many consumers and suppliers [93]. Heat pump combined with heat storage utilizing wind power locally was also demonstrated in [94] . It is also showed excess heat from industrial thermal processes within $5 \mathrm{~km}$ by $5 \mathrm{~km}$ Danish Square Grid in Denmark [95]. A 
map of excess heat from industrial thermal processes and heat sources in Denmark relative to heat demand summarized per municipality was shown in the reference [96].

Danish government has ambitious plan to develop the wind energy systems for electricity. Wind turbines delivered power equivalent to 43.6 percent of Denmark's electricity consumption in 2017 [97]. This is a new milestone in the effort to transform the energy supply system in the country to be carbon neutral. A large share of electricity from wind energy into the electricity grid will result in that CHP plant will not be operated so frequently. It is not economic to operate CHP only for heat. Noussan et al. [98] reported the similar conclusion for Italian context with high penetration of renewables in the electricity mix. Other heat sources, including waster heat, heat from heat pumps (using wind power), biomass boilers, and solar district heating plants, will become more and more interesting for district heating networks. The mentioned renewable heat resources together with short-term and long-term storages can make $100 \%$ renewable district heating networks possible.

Large-scale compression heat pumps would improve the integration between the district

\section{Discussions} photovoltaic and other sources. A potential for introducing heat pumps in Denmark between 2 and $4 \mathrm{GW}$-thermal power and a total potential benefit around $100 \mathrm{MW} / \mathrm{year}$ in 2025 was found by the Lund et al [99]. Seasonal thermal energy storage systems alongside heat pumps have received an increasing attention in Denmark [100]. Centralized district heating based on heat pumps and large storages is a cost-effective solution, when there is excess electricity from wind turbines [101]. As aforementioned, large solar heating systems and biomass boilers are already a cost-effective solution for district heating networks in Denmark. Parabolic trough collectors can be put into defocus and focus during operation with smart control [84]. So solar heat from parabolic trough collectors is one kind of boiler for district heating systems. The systematic integration of central solar heating plants, heat pumps driven by excess renewable electricity, biomass boilers with large long-term \& short-term storage components can be an alternative solution for high renewable penetration in the district heating systems. District heating networks with $100 \%$ renewable energy can be a reality in the near future. Furthermore, higher penetration of wind and solar energy in the energy mix together with storage technologies can increase flexibility to cope with variability in power generation, and redispatch in case of forecast errors [102].

The success key factors for solar district heating plants in Denmark can be summarized as follows [103]: profound district heating networks, cheap land, cost-effectiveness of ground mounted collectors, high collector efficiency, long lifetime of the collector, high energy tax on natural gas, competitive heat production price, interaction with liberal electricity market.

The advantages of solar thermal energy reduce in terms of fossil fuel and CO2-emission reductions when transitioning towards a high-renewable energy system in the near future [104]. In fact, the main and final goal of the district heating utilities is to achieve the lowest possible heat 
price for their customers, which requires a holistic approach - especially when the number of heat production options is increased. Size of solar collector fields, storage volume, and dynamic behavior of annual heat demand depends on each other closely. The optimization of these three mentioned parameters should be carried out when planning and designing solar district heating plants in order to achieve cost-effective solar heat for consumers. If there is no large storage components available for solar collector field, the size of solar collector field will be limited by the low heat demand in the summer period. Night cooling can be implemented to avoid overheating production of a solar collector field during the very few really sunny period. If seasonal storage can be used in the district heating plants in a cost-effective way, the solar fraction can increase dramatically. Another solution to avoid overheat production can be using tracking collector, such as parabolic trough collectors. The tracking collectors can be partially defocused in summer if the solar heat is not needed for short periods. With defocus of tracking collector, the requirement of a large storage volume also can be avoided.

The building energy system areas can be divided into heating dominated area, heating \& cooling balanced area, and cooling dominated area in the household sector. The leading countries of solar district heating systems in Europe are Denmark, Germany and Austria. The experiences presented in this study mainly are suitable for heating dominated areas in the world. Combined district heating and cooling systems integrated with seasonal storage, such as borehole thermal energy storage [105], has not been fully explored so far.

\section{Conclusions and policy implications}

A comprehensive analysis on the development of large solar district heating plants in Denmark are carried out. The development of solar district heating plants in Denmark has been clarified. Typical components of solar district heating plants have been summarized. The possibility of solar heating plants integrated with other renewable energy sources have been discussed. The following main conclusions may be drawn:

1. Low solar heat price is the main driving force of large solar district heating plants in Denmark. High heat price of electricity and natural gas boiler systems results in that the solar heat is very competitive for the end-users.

2. District heating companies are mainly owned by the end-users community. The consumers have the willingness to build solar district heating plants. Normally the land is very cheap.

3. High penetration of district heating networks in Denmark reduces the initial investment cost of solar heating plants. More than $64 \%$ of heat demand of Danish household is supplied by district heating networks.

4. Reliable solar collector components: Arcon-Sunmark A/S solar collectors are used in more than $70 \%$ solar heating plants in the market. High efficiency of large area solar collectors and long lifetime guarantees that the market has gained great confidence in the 

solar district heating market. This corresponds to an efficiency of around $40 \%$ in solar collector fields in Denmark (40\% of the available solar irradiation is utilized).

The recommendations for future replicability in other countries are as follows:

1. Reliable solar collectors with long life time should be provided in the solar district heating systems. Performance guarantee should be done in order to increase the market confidence for the end-users.

2. Professional design and operation of solar district heating plants needs to be addressed carefully.

3. Heat price of solar heat should be evaluated to compare to local fossil energy systems, like natural gas boilers.

4. The policy-makers, consultant company and end-users should be updated about the whole process when a solar heating plant is implemented.

\section{Acknowledgments}

This study was partly done when the first author (Zhiyong Tian) was the $\mathrm{PhD}$ student in Technical University of Denmark. The PhD study of Zhiyong Tian was partly funded by China Scholarship Council (No. 201506120074). Zhiyong Tian is working at the Department of Civil and Environmental Engineering in Norwegian University of Science and Technology (Postdoctoral Fellow). This research work is also under the framework of IEA-SHC Task 55 -Towards the Integration of Large SHC Systems into District Heating and Cooling (DHC) Networks. The second author expresses thanks to financial support of the National Key R\&D Program of China (2017YFC0702600).

\section{References}

[1] A. Lake, B. Rezaie, and S. Beyerlein, "Review of district heating and cooling systems for a sustainable future," Renew. Sustain. Energy Rev., vol. 67, pp. 417-425, Jan. 2017.

[2] M. A. Sayegh et al., "Trends of European research and development in district heating technologies," Renew. Sustain. Energy Rev., vol. 68, pp. 1183-1192, Feb. 2017.

[3] European Commission, "Buildings - European Commission," https://ec.europa.eu/energy/en/topics/energy-efficiency/buildings, 2018. [Online]. Available: https://ec.europa.eu/energy/en/topics/energyefficiency/buildings. [Accessed: 23-Apr-2018].

[4] European Commission, "Heating and cooling - European Commission," 2016. [Online]. Available: https://ec.europa.eu/energy/en/topics/energyefficiency/heating-and-cooling. [Accessed: 25-May-2018].

[5] M. G. Fernández, C. Roger-Lacan, U. Gährs, and V. Aumaitre, Efficient district 
heating and cooling systems in the EU, no. December. 2016.

[6] J. Deng, Z. Tian, J. Fan, M. Yang, S. Furbo, and Z. Wang, "Simulation and optimization study on a solar space heating system combined with a low temperature ASHP for single family rural residential houses in Beijing," Energy Build., vol. 126, pp. 2-13, 2016.

[7] E. Carpaneto, P. Lazzeroni, and M. Repetto, "Optimal integration of solar energy in a district heating network," Renew. Energy, vol. 75, pp. 714-721, 2015 .

[8] D. Buoro, P. Pinamonti, and M. Reini, "Optimization of a distributed cogeneration system with solar district heating," Appl. Energy, vol. 124, pp. 298-308, 2014.

[9] J.-O. Dalenbäck, "Large-Scale Solar Heating and Cooling Systems in Europe," in Proceedings of ISES World Congress 2007 (Vol. I - Vol. V), Berlin, Heidelberg: Springer Berlin Heidelberg, 2008, pp. 799-803.

[10] IEA-SHC, "IEA SHC-Task 07 Central Solar Heating Plants With Seasonal Storage.” [Online]. Available: http://task07.iea-shc.org/. [Accessed: 10-Oct2018].

[11] J. E. Nielsen, "IEA-SHC Task 45: Large Solar Heating/Cooling Systems, Seasonal Storage, Heat Pumps," Energy Procedia, vol. 30, pp. 849-855, Jan. 2012.

[12] IEA-SHC, "IEA SHC Task 55-Towards the Integration of Large SHC Systems into District Heating and Cooling (DHC) Networks." [Online]. Available: http://task55.iea-shc.org/. [Accessed: 10-Oct-2018].

[13] W. Weiss and M. Spörk-Dür, "Solar Heat Worldwide 2018 version (Global Market Development and Trends in 2017 Detailed Market Figures 2016)," 2018.

[14] N. Perez-Mora et al., "Solar district heating and cooling: A review," Int. J. Energy Res., vol. 42, no. 4, pp. 1419-1441, Mar. 2018.

[15] T. Schmidt, D. Mangold, and H. Müller-Steinhagen, "Central solar heating plants with seasonal storage in Germany," Sol. Energy, vol. 76, no. 1-3, pp. 165-174, Jan. 2004.

[16] A. Tonhammar, "The potential of a large scale solar district heating facility in Stockholm solar district heating facility in Stockholm," no. January, 2014.

[17] P. Reiter, H. Poier, and C. Holter, "BIG solar graz: solar district heating in Graz - 500,000 m2 for 20\% solar fraction," Energy Procedia, vol. 91, pp. 578-584, 
2016.

[18] T. Urbaneck et al., "Solar district heating in East Germany - transformation in a cogeneration dominated city," Energy Procedia, vol. 70, pp. 587-594, 2015.

[19] D. Bauer, R. Marx, and H. Drück, "Solar District Heating for the Built Environment-Technology and Future Trends within the European Project EINSTEIN," Energy Procedia, vol. 57, no. 0, pp. 2716-2724, 2014.

[20] V. Lottner, M. . Schulz, and E. Hahne, "Solar-Assisted District Heating Plants: Status of the German Programme Solarthermie-2000," Sol. Energy, vol. 69, no. 6, pp. 449-459, Jan. 2000.

[21] I. Ben Hassine and U. Eicker, "Impact of load structure variation and solar thermal energy integration on an existing district heating network," Appl. Therm. Eng., vol. 50, no. 2, pp. 1437-1446, Feb. 2013.

[22] B. Welsch, L. Göllner-Völker, D. O. Schulte, K. Bär, I. Sass, and L. Schebek, "Environmental and economic assessment of borehole thermal energy storage in district heating systems," Appl. Energy, vol. 216, pp. 73-90, 2018.

[23] R. Soloha, I. Pakere, and D. Blumberga, "Solar energy use in district heating systems. A case study in Latvia," Energy, vol. 137, pp. 586-594, 2017.

[24] G. Ciampi, A. Rosato, and S. Sibilio, "Thermo-economic sensitivity analysis by dynamic simulations of a small Italian solar district heating system with a seasonal borehole thermal energy storage," Energy, vol. 143, pp. 757-771, Jan. 2018.

[25] A. Carotenuto, R. D. Figaj, and L. Vanoli, "A novel solar-geothermal district heating, cooling and domestic hot water system: Dynamic simulation and energy-economic analysis," Energy, vol. 141, pp. 2652-2669, 2017.

[26] J. Felipe Andreu, D. R. Schneider, and G. Krajačić, "Evaluation of integration of solar energy into the district heating system of the city of Velika Gorica," Therm. Sci., vol. 20, no. 4, pp. 1049-1060, 2016.

[27] J. Lizana, C. Ortiz, V. M. Soltero, and R. Chacartegui, "District heating systems based on low-carbon energy technologies in Mediterranean areas," Energy, vol. 120, pp. 397-416, Feb. 2017.

[28] V. Tulus, D. Boer, L. F. Cabeza, L. Jimenez, and G. Guillen-Gosalbez, "Enhanced thermal energy supply via central solar heating plants with seasonal storage: A multi-objective optimization approach," Appl. Energy, vol. 181, pp. 549-561, 2016. 
[29] M. De Guadalfajara, M. A. Lozano, and L. M. Serra, "Evaluation of the potential of large solar heating plants in Spain," Energy Procedia, vol. 30, pp. 839-848, 2012.

[30] C. Winterscheid, J.-O. Dalenbäck, and S. Holler, "Integration of solar thermal systems in existing district heating systems," Energy, vol. 137, pp. 579-585, Oct. 2017.

[31] J. Hirvonen, H. Ur Rehman, and K. Sirén, "Techno-economic optimization and analysis of a high latitude solar district heating system with seasonal storage, considering different community sizes," Sol. Energy, vol. 162, pp. 472-488, 2018.

[32] H. ur Rehman, J. Hirvonen, and K. Sirén, "Performance comparison between optimized design of a centralized and semi-decentralized community size solar district heating system," Appl. Energy, vol. 229, pp. 1072-1094, Nov. 2018.

[33] H. ur Rehman, J. Hirvonen, and K. Sirén, "A long-term performance analysis of three different configurations for community-sized solar heating systems in high latitudes," Renew. Energy, vol. 113, pp. 479-493, Dec. 2017.

[34] M. Rämä and S. Mohammadi, "Comparison of distributed and centralised integration of solar heat in a district heating system," Energy, vol. 137, pp. 649660, Oct. 2017.

[35] V. Tulus, M. H. Abokersh, L. F. Cabeza, M. Vallès, L. Jiménez, and D. Boer, "Economic and environmental potential for solar assisted central heating plants in the EU residential sector: Contribution to the 2030 climate and energy EU agenda," Appl. Energy, vol. 236, pp. 318-339, Feb. 2019.

[36] N. Pardo García, G. Zubi, G. Pasaoglu, and R. Dufo-López, "Photovoltaic thermal hybrid solar collector and district heating configurations for a Central European multi-family house," Energy Convers. Manag., vol. 148, pp. 915-924, Sep. 2017.

[37] S. Salehi, M. Yari, and M. A. Rosen, "Exergoeconomic comparison of solarassisted absorption heat pumps, solar heaters and gas boiler systems for district heating in Sarein Town, Iran," Appl. Therm. Eng., vol. 153, pp. 409-425, May 2019.

[38] T. Bouhal et al., "Technical assessment, economic viability and investment risk analysis of solar heating/cooling systems in residential buildings in Morocco," Sol. Energy, vol. 170, pp. 1043-1062, Aug. 2018.

[39] I. Pakere, D. Lauka, and D. Blumberga, "Solar power and heat production via 
[40] H. Jouhara et al., "The performance of a heat pipe based solar PV/T roof collector and its potential contribution in district heating applications," Energy,

photovoltaic thermal panels for district heating and industrial plant," Energy, vol. 154, pp. 424-432, 2018. vol. 136, pp. 117-125, Oct. 2017.

[41] L. Xu, J. I. Torrens, F. Guo, X. Yang, and J. L. M. Hensen, “Application of large underground seasonal thermal energy storage in district heating system: A model-based energy performance assessment of a pilot system in Chifeng, China," Appl. Therm. Eng., vol. 137, pp. 319-328, Jun. 2018.

[42] B. Sibbitt et al., "Measured and simulated performance of a high solar fraction district heating system with seasonal storage," Proc. Ises Sol. World Congr. 2011, Swc 2011, pp. 3037-3048, 2011.

[43] Drake landing solar community, "Drake landing solar community," http://www.dlsc.ca/, 2017. [Online]. Available: July.2017.

[44] A. L. Reed, A. P. Novelli, K. L. Doran, S. Ge, N. Lu, and J. S. Mccartney, "Solar district heating with underground thermal energy storage: Pathways to commercial viability in North America *," Renew. Energy, vol. 126, pp. 1-13, 2018.

[45] R. Renaldi and D. Friedrich, "Techno-economic analysis of a solar district heating system with seasonal thermal storage in the UK," Appl. Energy, vol. 236, pp. 388-400, Feb. 2019.

[46] C. Flynn and K. Siren, "Influence of location and design on the performance of a solar district heating system equipped with borehole seasonal storage," Renew. Energy, vol. 81, pp. 377-388, 2015.

[47] H. J. Quintana and M. Kummert, "Optimized control strategies for solar district heating systems," J. Build. Perform. Simul., vol. 8, no. 2, pp. 79-96, Mar. 2015.

[48] F. M. Rad, A. S. Fung, and M. A. Rosen, "An integrated model for designing a solar community heating system with borehole thermal storage," Energy Sustain. Dev., vol. 36, pp. 6-15, 2017.

[49] S. Furbo, J. Fan, B. Perers, W. Kong, D. Trier, and N. From, "Testing, development and demonstration of large scale solar district heating systems," Energy Procedia, vol. 70, pp. 568-573, 2015.

[50] A. Arabkoohsar and G. B. Andresen, "Supporting district heating and cooling networks with a bifunctional solar assisted absorption chiller," Energy Convers. 
Manag., vol. 148, pp. 184-196, Sep. 2017.

686

687

688

689

690

691

692

693

694

695

696

697

698

699

700

701

702

703

704

705

706

707

708

709

710

711

712

713

714

715

716

717

718

[51] F. Bava and S. Furbo, "Impact of different improvement measures on the thermal performance of a solar collector field for district heating," Energy, vol. 144, pp. 816-825, Feb. 2018.

[52] "New ambitious Danish energy agreement secured," 2018. [Online]. Available: https://investindk.com/insights/new-ambitious-danish-energy-agreement. [Accessed: 20-Mar-2019].

[53] Danish Energy Agency, "Regulation and planning of district heating in Denmark," https://ens.dk/sites/ens.dk/files/Globalcooperation/regulation_and_planning_of _district_heating_in_denmark.pdf. [Online]. Available: Sep.2017.

[54] K. Jessen, "DISTRICT HEATING in The Danish Energy System," https://northsearegion.eu/media/1531/the-danish-energy-system-case-dh.pdf.

[55] PlanEnergi, "Solar District Heating in Denmark 1988-2018," http://planenergi.eu/activities/district-heating/solar-district-heating/sdh-in-dk1988-2018/, 2018. [Online]. Available: http://planenergi.eu/activities/districtheating/solar-district-heating/sdh-in-dk-1988-2018/. [Accessed: 27-Feb-2018].

[56] PlanEnergi, "planenergi," http://planenergi.eu/activities/fjernvarme/solarheating/, 2017. [Online]. Available: 2017.

[57] T. Daniel, B. Federico, and S. Christian, Kok Skov Simon Stendorf, "Solar District Heating Trends and Possibilities - Characteristics of Ground-Mounted Systems for Screening of Land Use Requirements and Feasibility," 2018.

[58] M. Fish, M. Guigas, and J. Dalenback, "A review of large-scale solar heating systems in Europe," Sol. Energy, vol. 63, no. 6, pp. 355-66, 1998.

[59] A. Heller, "15 Years of R\&amp;D in central solar heating in Denmark," Sol. Energy, vol. 69, no. 6, pp. 437-447, Jan. 2000.

[60] Z. Tian, B. Perers, S. Furbo, J. Fan, J. Deng, and J. Dragsted, “A Comprehensive Approach for Modelling Horizontal Diffuse Radiation, Direct Normal Irradiance and Total Tilted Solar Radiation Based on Global Radiation under Danish Climate Conditions," Energies, vol. 11, no. 5, p. 1315, May 2018.

[61] Solargis, "Solargis," http://solargis.com/, 2018. [Online]. Available: Mar.2018.

[62] S. Furbo, J. Dragsted, B. Perers, E. Andersen, F. Bava, and K. P. Nielsen, "Yearly thermal performances of solar heating plants in Denmark - Measured and calculated," Sol. Energy, vol. 159, pp. 186-196, Jan. 2018. 
[63] M. Noussan, M. Jarre, L. Degiorgis, and A. Poggio, "Data Analysis of the Energy Performance of Large Scale Solar Collectors for District Heating," Energy Procedia, vol. 134, pp. 61-68, 2017.

[64] F. Gram, “Gram Fjernvarme.” 2016.

[65] J. Larsen, "Solar systems and district heating Braedstrup District Heating."

[66] Arcon-Sunmark, "Arcon-Sunmark A/S," http://arcon-sunmark.com/products. [Online]. Available: Mar.2018.

[67] Z. Liu, H. Li, K. Liu, H. Yu, and K. Cheng, "Design of high-performance water-in-glass evacuated tube solar water heaters by a high-throughput screening based on machine learning: A combined modeling and experimental study," Sol. Energy, vol. 142, pp. 61-67, Jan. 2017.

[68] J. Huang, Z. Tian, and J. Fan, "A comprehensive analysis on development and transition of the solar thermal market in China with more than $70 \%$ market share worldwide," Energy, vol. 174, pp. 611-624, Feb. 2019.

[69] SolarKeyMark, "Solar Keymark Certification," http://www.solarkeymark.dk/, 2017. [Online]. Available: October 2017.

[70] A. Dahash, F. Ochs, M. B. Janetti, and W. Streicher, "Advances in seasonal thermal energy storage for solar district heating applications: A critical review on large-scale hot-water tank and pit thermal energy storage systems," Appl. Energy, vol. 239, pp. 296-315, Apr. 2019.

[71] H. Wang, W. Yin, E. Abdollahi, R. Lahdelma, and W. Jiao, "Modelling and optimization of CHP based district heating system with renewable energy production and energy storage," Appl. Energy, vol. 159, pp. 401-421, 2015.

[72] T. Daniel, K. S. Christian, and S. S. Simon, "POTENTIALS FOR GROUNDMOUNTED SDH IN EUROPE," in 2018 International Solar Heating Conference Proceeding, 2018.

[73] D. Trier, "Towards solar district heating with more than $70 \%$ solar fraction," Energy Procedia, vol. 70, pp. 580-586, 2015.

[74] A. Sørensen and T. Schmidt, "Design and Construction of Large Scale Heat Storages for District Heating in Denmark," in International Conference on Energy Storage, 2018.

[75] Danish Energy Agency, "Technology Data For Energy Plants (Update of chapter 46 Solar District Heating)," 2018. 
[76] D. Olsthoorn, F. Haghighat, and P. A. Mirzaei, "Integration of storage and renewable energy into district heating systems: A review of modelling and optimization," Sol. Energy, vol. 136, pp. 49-64, 2016.

[77] Y. Louvet et al., "LCOH for Solar Thermal Applications LCOH for Solar Thermal Applications Conventional reference system," http://task54.ieashc.org/, 2017. [Online]. Available: July.2017.

[78] H. Lund et al., "The status of 4th generation district heating: Research and results," Energy, vol. 164, pp. 147-159, Dec. 2018.

[79] B. Perers, S. Furbo, Z. Tian, J. Egelwisse, F. Bava, and J. Fan, "Tårs 10000 m2 CSP + flat plate solar collector plant - cost-performance optimization of the design," Energy Procedia, vol. 91, pp. 312-316, 2016.

[80] D. Krueger et al., "Parabolic trough collectors for district heating systems at high latitudes," in Proceedings of Eurosun, 2000.

[81] Aalborg CSP A/S, “Aalborg CSP," http://www.aalborgcsp.com/, 2018. [Online]. Available: Mar.2018.

[82] Z. Tian, Solar heating plants with flat plate collectors and parabolic trough collectors. DTU, 2018.

[83] Z. Tian, B. Perers, S. Furbo, and J. Fan, "Analysis and validation of a quasidynamic model for a solar collector field with flat plate collectors and parabolic trough collectors in series for district heating," Energy, vol. 142, pp. 130-138, Jun. 2018.

[84] Z. Tian, B. Perers, S. Furbo, and J. Fan, "Thermo-economic optimization of a hybrid solar district heating plant with flat plate collectors and parabolic trough collectors in series," Energy Convers. Manag., vol. 165, pp. 92-101, Jun. 2018.

[85] Z. Tian, B. Perers, S. Furbo, and J. Fan, “Annual measured and simulated thermal performance analysis of a hybrid solar district heating plant with flat plate collectors and parabolic trough collectors in series," Appl. Energy, vol. 205, pp. 417-427, 2017.

[86] A. Modi, F. Bühler, J. G. Andreasen, and F. Haglind, "A review of solar energy based heat and power generation systems," Renew. Sustain. Energy Rev., vol. 67, pp. 1047-1064, Jan. 2017.

[87] A. Zourellis, B. Perers, J. Donneborg, and J. Matoricz, "Optimizing Efficiency of Biomass-Fired Organic Rankine Cycle with Concentrated Solar Power in Denmark," Energy Procedia, vol. 149, pp. 420-426, Sep. 2018. 
[88] B. Ahlgren et al., "A simplified model for linear correlation between annual yield and DNI for parabolic trough collectors," Energy Convers. Manag., vol. 174, pp. 295-308, Oct. 2018.

[89] Absolicon, "Absolicon Solar Collector AB," http://www.absolicon.se/absolicon-t160/, 2018. [Online]. Available: Feb.2018.

[90] X. Yang, H. Li, and S. Svendsen, "Energy, economy and exergy evaluations of the solutions for supplying domestic hot water from low-temperature district heating in Denmark," Energy Convers. Manag., vol. 122, pp. 142-152, Aug. 2016.

[91] Y. Li, Y. Rezgui, and H. Zhu, "District heating and cooling optimization and enhancement - Towards integration of renewables, storage and smart grid," Renew. Sustain. Energy Rev., vol. 72, pp. 281-294, May 2017.

[92] R. Marx, H. Drück, D. Bauer, and H. Drueck, "Energy Efficient Integration of Heat Pumps into Solar District Heating Systems with Seasonal Thermal Energy Storage," Energy Procedia, vol. 57, pp. 2706-2715, 2014.

[93] B. Bach, J. Werling, T. Ommen, M. Münster, J. M. Morales, and B. Elmegaard, "Integration of large-scale heat pumps in the district heating systems of Greater Copenhagen," Energy, vol. 107, pp. 321-334, 2016.

[94] P. A. Østergaard, J. Jantzen, H. M. Marczinkowski, and M. Kristensen, "Business and Socioeconomic Assessment of Introducing Heat Pumps with Heat Storage in Small-Scale District Heating Systems," Renew. Energy, Mar. 2019.

[95] F. Bühler, S. Petrović, K. Karlsson, and B. Elmegaard, "Industrial excess heat for district heating in Denmark," Appl. Energy, vol. 205, pp. 991-1001, Nov. 2017.

[96] R. Lund and U. Persson, "Mapping of potential heat sources for heat pumps for district heating in Denmark," Energy, vol. 110, pp. 129-138, Sep. 2016.

[97] “44\% Wind - Denmark Set New Wind Energy Record In 2017| CleanTechnica." [Online]. Available: https://cleantechnica.com/2018/01/06/44wind-denmark-smashed-already-huge-wind-energy-records-2017/. [Accessed: 12-Aug-2018].

[98] M. Noussan, M. Jarre, R. Roberto, and D. Russolillo, "Combined vs separate heat and power production - Primary energy comparison in high renewable share contexts," Appl. Energy, vol. 213, pp. 1-10, Mar. 2018. 
[99] R. Lund, D. D. Ilic, and L. Trygg, "Socioeconomic potential for introducing large-scale heat pumps in district heating in Denmark," J. Clean. Prod., vol. 139, pp. 219-229, Dec. 2016.

[100] P. Sorknæs, "Simulation method for a pit seasonal thermal energy storage system with a heat pump in a district heating system," Energy, vol. 152, pp. 533-538, Jun. 2018.

[101] A. Pensini, C. N. Rasmussen, and W. Kempton, "Economic analysis of using excess renewable electricity to displace heating fuels," Appl. Energy, vol. 131, pp. 530-543, 2014.

[102] P. Pinson, L. Mitridati, C. Ordoudis, and J. Ostergaard, "Towards fully renewable energy systems: Experience and trends in Denmark," CSEE J. Power Energy Syst., vol. 3, no. 1, pp. 26-35, Mar. 2017.

[103] J. E. Nielsen, "Solar District Heating - Why so Successful in Denmark Solar District Heating - Why so Successful in Denmark Denmark plans to : Phase out all fossil fuels before 2050," 2014.

[104] K. Hansen and B. Vad Mathiesen, "Comprehensive assessment of the role and potential for solar thermal in future energy systems," Sol. Energy, vol. 169, pp. 144-152, Jul. 2018.

[105] F. M. Rad and A. S. Fung, "Solar community heating and cooling system with borehole thermal energy storage - Review of systems," Renew. Sustain. Energy Rev., vol. 60, pp. 1550-1561, Jul. 2016. 